\title{
The impact of melt ponds on summertime microwave brightness temperatures and sea-ice concentrations
}

\author{
Stefan Kern ${ }^{1}$, Anja Rösel ${ }^{2}$, Leif Toudal Pedersen ${ }^{3}$, Natalia Ivanova $^{4}$, Roberto Saldo $^{5}$, and Rasmus Tage Tonboe ${ }^{3}$ \\ ${ }^{1}$ Center for Climate System Analysis and Prediction CliSAP, Hamburg, Germany \\ ${ }^{2}$ Norsk Polar Institute, Tromsø, Norway \\ ${ }^{3}$ Danish Meteorological Institute, Copenhagen, Denmark \\ ${ }^{4}$ Nansen Environmental and Remote Sensing Center NERSC, Bergen, Norway \\ ${ }^{5}$ Danish Technical University-Space, Copenhagen, Denmark
}

Correspondence to: Stefan Kern (stefan.kern@uni-hamburg.de)

Received: 1 November 2015 - Published in The Cryosphere Discuss.: 15 January 2016

Revised: 19 July 2016 - Accepted: 26 July 2016 - Published: 26 September 2016

\begin{abstract}
Sea-ice concentrations derived from satellite microwave brightness temperatures are less accurate during summer. In the Arctic Ocean the lack of accuracy is primarily caused by melt ponds, but also by changes in the properties of snow and the sea-ice surface itself. We investigate the sensitivity of eight sea-ice concentration retrieval algorithms to melt ponds by comparing sea-ice concentration with the melt-pond fraction. We derive gridded daily sea-ice concentrations from microwave brightness temperatures of summer 2009. We derive the daily fraction of melt ponds, open water between ice floes, and the ice-surface fraction from contemporary Moderate Resolution Spectroradiometer (MODIS) reflectance data. We only use grid cells where the MODIS seaice concentration, which is the melt-pond fraction plus the ice-surface fraction, exceeds $90 \%$. For one group of algorithms, e.g., Bristol and Comiso bootstrap frequency mode (Bootstrap_f), sea-ice concentrations are linearly related to the MODIS melt-pond fraction quite clearly after June. For other algorithms, e.g., Near90GHz and Comiso bootstrap polarization mode (Bootstrap_p), this relationship is weaker and develops later in summer. We attribute the variation of the sensitivity to the melt-pond fraction across the algorithms to a different sensitivity of the brightness temperatures to snow-property variations. We find an underestimation of the sea-ice concentration by between $14 \%$ (Bootstrap_f) and $26 \%$ (Bootstrap_p) for $100 \%$ sea ice with a melt-pond fraction of $40 \%$. The underestimation reduces to $0 \%$ for a meltpond fraction of $20 \%$. In presence of real open water between ice floes, the sea-ice concentration is overestimated by
\end{abstract}

between $26 \%$ (Bootstrap_f) and 14\% (Bootstrap_p) at $60 \%$ sea-ice concentration and by $20 \%$ across all algorithms at $80 \%$ sea-ice concentration. None of the algorithms investigated performs best based on our investigation of data from summer 2009. We suggest that those algorithms which are more sensitive to melt ponds could be optimized more easily because the influence of unknown snow and sea-ice surface property variations is less pronounced.

\section{Introduction}

Sea-ice area and extent are derived from the sea-ice concentration, i.e., the fraction of a given area of the ocean covered with sea ice. Observations of the brightness temperature by satellite passive microwave sensors have been the backbone of sea-ice concentration retrieval for more than 35 years because these are independent of daylight and are quite insensitive to the cloud cover. These satellite sensors measure the brightness temperature at window frequencies between 6 and $\sim 90 \mathrm{GHz}$ at vertical and horizontal polarization, at a constant incidence angle of $\sim 53^{\circ}$, which we use for the present paper. Numerous sea-ice concentration retrieval algorithms have been developed during the past decades (see e.g., Ivanova et al., 2015). To retrieve the sea-ice concentration, all algorithms exploit the contrast in the microwave brightness temperature between open water and sea ice in some way. During cold conditions, i.e., as long as freezing conditions prevail, sea-ice concentrations are retrieved with 
these algorithms as accurate as $2-5 \%$ for the near $100 \%$ ice cover (Ivanova et al., 2015, 2014; Andersen et al., 2007; Meier, 2005). However, during melting conditions, the retrieval accuracy is reduced substantially and sea-ice concentrations can be biased low compared to the actual sea-ice concentration (Ivanova et al., 2013; Rösel et al., 2012b; Comiso and Kwok, 1996; Steffen and Schweiger, 1991; Cavalieri et al., 1990).

One potential reason for the reduced accuracy is the change in microphysical properties inside the sea ice, for instance, the desalination of the sea ice during the melt process or the flushing of air voids in multiyear ice with meltwater and other melt processes, as for example described in Scharien et al. (2010). Another potential reason is the change in surface properties of the sea ice. The three key surface features of summer melt on Arctic sea ice are a metamorphous, wet snow cover, a porous, wet sea-ice surface, and melt ponds. During summer, the snow cover on sea ice is usually wet or even saturated with meltwater (Garrity, 1992). Its density is usually considerably larger during summer than during winter (Warren et al., 1999; Maykut and Untersteiner, 1971). Diurnal melt-refreeze cycles, i.e., episodes of intermittent melting and refreezing of the snow, which is a common phenomenon during late spring, result in an increase in the snow grain size.

Wet snow is an efficient absorber of microwave radiation and has a microwave emissivity close to 1 . It can effectively block microwave emission from underneath, and thereby masks differences in volume scattering between first-year and multiyear ice. Therefore microwave brightness temperatures of sea ice covered with wet snow usually are close to its physical temperature during melt (e.g., Stiles and Ulaby, 1980; Eppler et al., 1992; Hallikainen and Winebrenner, 1992; Garrity, 1992).

During the melt phase of melt-refreeze cycles, coarsegrained snow can be regarded to behave similarly to wet snow due to its wetness. During the refreeze phase, however, when it is dry, it absorbs less microwave radiation than wet snow, and there is more scattering from within the snow. Therefore, dry coarse-grained snow does not block or mask microwave emission and volume scattering differences of the sea ice and/or snow underneath as efficiently as wet snow does. The amount of volume scattering depends on microwave frequency and polarization, and on the vertical location of the coarse-grained snow layers relative to the snow surface. Because the electromagnetic wavelengths are closer to the snow grain size at higher frequencies, i.e., at $37-90 \mathrm{GHz}$, volume scattering in snow is larger for the higher than the lower microwave frequencies (Fuhrhop et al., 1998; Eppler et al., 1992; Hallikainen and Winebrenner, 1992; Gogineni et al., 1992). In Tables 1-3 we give some sensitivities of microwave brightness temperatures with respect to changes in snow wetness, density, and grain size. These tables are not meant to be exhaustive. Instead we will use the sensitivities for our discussion of the results (Sect. 4).
Melt ponds are puddles of meltwater on top of sea ice. They form during summer from melting snow and sea ice. Their areal fraction, size and depth is determined by the onset, length and severity of the melting season, the seaice type and topography, and the snow-depth distribution at the beginning of melt (Landy et al., 2014; Polashenski et al., 2012; Petrich et al., 2012; Eicken et al., 2004; Perovich et al., 2002). The melt-pond water salinity is close to 0 ppt. Typically, the melt-pond fraction on Arctic sea ice varies between 10 and $40 \%$ but can also exceed $50 \%$, for instance, early in the melt season or on land-fast sea ice (Webster et al., 2015; Divine et al., 2015; Landy et al., 2014; Polashenski et al., 2012; Sankelo et al., 2010; Tschudi et al., 2001; Yackel and Barber, 2000; Fetterer and Untersteiner, 1998).

The penetration depth into liquid water of microwave radiation at the frequencies used here, i.e., between 6 and $89 \mathrm{GHz}$, is of the order of $1 \mathrm{~mm}$ (Ulaby et al., 1986). We use the penetration depth here as the depth from which most of the microwave radiation originates. Because of the abovementioned very low penetration depth, a water layer with a depth of a few millimeters is opaque enough to completely block the microwave signal from the sea ice underneath. A melt pond on sea ice has the brightness-temperature signal of open water, and is therefore indistinguishable from open water in cracks or leads between the sea-ice floes (Gogineni et al., 1992; Grenfell and Lohanick, 1985). At $6 \mathrm{GHz}$ and higher frequencies, the signature of freshwater and saltwater are indistinguishable. Satellite microwave sensors which have been used for sea-ice concentration retrieval allow for footprint sizes between $\sim 5$ and $\sim 70 \mathrm{~km}$. Melt ponds, cracks, and leads are therefore sub-footprint size surface features, and cannot be resolved individually. A satellite brightnesstemperature measurement of a mixed scene is therefore composed of contributions from the open water, i.e., cracks, leads, melt ponds, and from the (snow covered) sea ice. This has two main consequences for a sea-ice concentration product computed from such coarse-resolution satellite measurements. The sea-ice concentration in the presence of melt ponds is likely to be underestimated - because melt ponds are seen as open water. Whether the footprint contains, for example, (case A) $100 \%$ sea ice with $40 \%$ melt ponds or (case B) $60 \%$ sea ice with $40 \%$ open water from leads and openings, is ambiguous. In both cases, satellite microwave radiometry retrieves $60 \%$ sea-ice concentration because the net sea-ice surface fraction of sea ice in the grid cells is $60 \%$. If during summer, a sea-ice concentration retrieval algorithm overestimates the net sea-ice surface fraction in case A, for example because of a specific summertime microwave signature of the sea ice, and provides, e.g., $\sim 90 \%$ sea-ice concentration, then the same algorithm would most likely also overestimate the net sea-ice surface fraction in case B. The algorithm would hence underestimate the actual sea-ice concentration in case A but overestimate the actual sea-ice concentration in case B. 
Table 1. Typical values of changes in brightness temperature due to changes in snow wetness. Abbreviations TB, PR, GR, V, and H denote brightness temperature, normalized brightness-temperature polarization difference ("polarization ratio"), normalized brightness-temperature frequency difference ("gradient ratio"), vertical, and horizontal (polarization), respectively. Abbreviations E92, W14, and G92 refer to Eppler et al. (1992), Willmes et al. (2014), and Garrity (1992), respectively.

\begin{tabular}{|c|c|c|c|c|}
\hline Snow wetness & E92 & W14 & W14 & G92 \\
\hline Change by & Typical May-June increase $(\sim 2 \%)$ & Average May-June increase & Melt after refreeze & $+2 \%$ \\
\hline ТВ19H & $+25 \mathrm{~K}$ & $+16 \mathrm{~K}$ & $+5 \mathrm{~K}$ & - \\
\hline TB19V & $+20 \mathrm{~K}$ & $+14 \mathrm{~K}$ & $+7 \mathrm{~K}$ & - \\
\hline TB37H & $+40 \mathrm{~K}$ & $+32 \mathrm{~K}$ & $+25 \mathrm{~K}$ & $+34 \mathrm{~K}$ \\
\hline TB37V & $+30 \mathrm{~K}$ & $+32 \mathrm{~K}$ & $+10 \mathrm{~K}$ & $+15 \mathrm{~K}$ \\
\hline ТВ89H & - & $+50 \mathrm{~K}$ & - & - \\
\hline TB89V & - & $+60 \mathrm{~K}$ & - & - \\
\hline PR19 & - & - & +0.02 & - \\
\hline GR3719 & - & - & +0.05 & - \\
\hline
\end{tabular}

Table 2. Typical values of changes in brightness temperature due to changes in snow density. For abbreviations TB, PR, GR, V, and $\mathrm{H}$ see Table 1. Abbreviations F98 and B15 refer to Fuhrhop et al. (1998) and Beitsch (2014), respectively.

\begin{tabular}{lll}
\hline Snow density & F98 & B14 \\
\hline Change by & $+200 \mathrm{~kg} \mathrm{~m}^{-3}$ & $+50 \mathrm{~kg} \mathrm{~m}^{-3}$ \\
PR19 & +0.04 & - \\
GR3719 & 0.00 & - \\
TB89V-TB89H & - & $+2.5 \mathrm{~K}$ \\
\hline
\end{tabular}

This has consequences for climate research. For example, the sea-ice area, which is defined as the sum of the area of all sea-ice covered grid cells weighted by the sea-ice concentration, will be underestimated from case A but will be overestimated from case B. The ambiguity in the actual surface properties related to the sea-ice concentration value of $60 \%$ in the example above is also challenging for the initialization and evaluation of numerical models, and the assimilation of sea-ice concentration data into such models. An unambiguous sea-ice concentration is required for, e.g., the correct computation of the sea-ice volume. In the terminology of the more advanced thermo-dynamic and dynamic sea-ice models or model components which treat leads and melt ponds separately (e.g., Holland et al., 2012; Flocco et al., 2010), the fraction of sea ice covering the open ocean is called sea-ice concentration and includes melt ponds. The fraction of the latter is given separately as the area of the seaice surface covered by melt ponds and is called melt-pond fraction. It is obvious that such models would have difficulties using a sea-ice concentration product which is biased like described above for cases A and B. Even numerical models, which are not as advanced and which do not treat melt ponds separately, would have difficulties using such a product.

Approaches have been developed, which permit the meltpond fraction on sea ice to be derived from satellite observations in the visible/near-infrared frequency range (Istomina et al., 2015a, b; Zege et al., 2015; Rösel et al., 2012a). Their results could be used to correct the above-mentioned ambiguity by quantifying how much of the open water seen $(30 \%$ in the example above) is actually caused by melt ponds. However, the time series of melt-pond fraction data computed so far (2002-2009 and 2002-2011) are too short to apply such a correction for the entire sea-ice concentration data set, over 35 years long, from satellite microwave radiometry. In addition, such data may have limitations due to cloud cover and the viewing geometry at high latitudes (see Sect. 2.1).

This calls for a better quantification of the uncertainty and/or of potential biases in the sea-ice concentration. How sensitive are present-day sea-ice concentrations algorithms to the melt-pond fraction? How do these algorithms differ with respect to the expected bias due to melt ponds, and how can we explain these differences? We hypothesize that microwave brightness temperatures and sea-ice concentrations derived from them change linearly with the increase in surface-water fraction or the decrease in net sea-ice surface fraction due to melt ponds. To the authors' best knowledge, an intercomparison of different algorithms which incorporates contemporary information of the melt-pond fraction and an independent sea-ice concentration estimate, as is the aim of this study, has not previously been carried out.

In the present paper we illustrate how satellite microwave brightness-temperature measurements vary with the net sea-ice surface fraction derived from satellite visible/nearinfrared (VIS/NIR) imagery. We compare the sea-ice concentration obtained with different sea-ice concentration retrieval algorithms from these brightness temperatures with the seaice concentration and with the net sea-ice surface fraction from VIS/NIR imagery. We isolate the influence of meltpond fractions on the net sea-ice surface fraction by limiting our analysis to VIS/NIR imagery sea-ice concentrations $>90 \%$. We demonstrate how these brightness temperatures change with progression of melt and discuss the implications of this change for sea-ice concentration retrieval. 
Table 3. Typical values of changes in brightness temperature due to changes in snow grain size. For abbreviations TB, PR, GR, V, and H see Table 1. Abbreviations F98, W14, and G92 refer to Fuhrhop et al. (1998), Willmes et al. (2014), and Garrity (1992), respectively.

\begin{tabular}{lllll}
\hline Snow grain size & F98 & F98 & W14 & G92 \\
& Upper snow layer & Bottom snow layer & Upper snow layer & - \\
\hline Change by & $+0.5 \mathrm{~mm}$ & $+0.5 \mathrm{~mm}$ & $\begin{array}{l}\text { Increase due to } \\
\text { surface refreezing }\end{array}$ & $\begin{array}{l}\text { Increase due to surface } \\
\text { crust formation }\end{array}$ \\
GR3719 & -0.025 & +0.05 & -0.04 & - \\
PR19 & +0.01 & +0.02 & 0.0 & - \\
TB37V & - & - & $-20 \mathrm{~K}$ & $-10 \mathrm{~K}$ \\
TB37H & - & - & $-35 \mathrm{~K}$ & $-20 \mathrm{~K}$ \\
TB19V & - & - & $-10 \mathrm{~K}$ & - \\
TB19H & - & - & $-15 \mathrm{~K}$ & - \\
\hline
\end{tabular}

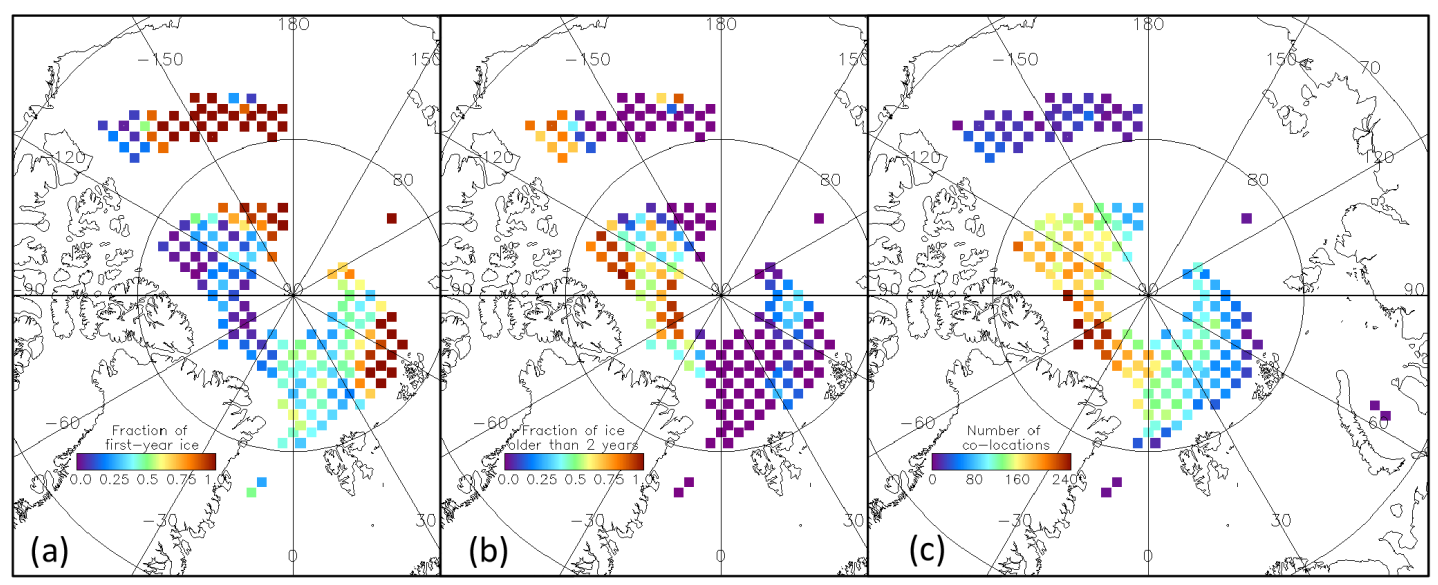

Figure 1. Spatial distribution of the MODIS sea-ice parameter data set superposed with the fraction of first-year ice (a), multiyear ice (b), and the number of co-located daily MODIS sea-ice parameter data for the entire period June-August (c).

The paper is organized as follows. Section 2 describes the data sets and methods used for the intercomparison of brightness temperatures and sea-ice concentrations derived with several algorithms and the melt-pond fraction. In Sect. 3 we are going to present the results of this intercomparison, which we discuss in Sect. 4. Section 5 concludes our findings.

\section{Data and methods}

The paper focuses on the melt season, i.e., the months of June, July, and August, of the year 2009. The spatial domain of our investigations is a region of the Arctic Ocean (see Fig. 1). This region is determined by the area and data which we chose to compute the sea-ice cover parameters from satellite VIS/NIR imagery, described in Sect. 2.1.

\subsection{Sea-ice parameters from VIS/NIR satellite imagery}

\subsubsection{Data sets and methodology}

We derive the open-water fraction, melt-pond fraction, and net sea-ice surface fraction from reflectance mea- surements of the Moderate Resolution Imaging Spectroradiometer (MODIS) aboard the Earth Observing System (EOS) satellite TERRA. We use the MODIS Surface Reflectance daily L2G Global $500 \mathrm{~m}$ and $1 \mathrm{~km}$ product (MOD09GA, http://reverb.echo.nasa.gov/reverb/). We obtain the $\mathrm{L} 2 \mathrm{G}$ data on the sinusoidal tile grid used for MODIS L2 data from http://landweb.nascom.nasa.gov/developers/ sn_tiles/sn_grid.html. We project the MODIS reflectance data together with land, cloud, and ancillary information onto the NSIDC polar stereographic grid with a tangential plane at $70^{\circ} \mathrm{N}$ with a grid resolution of $0.5 \mathrm{~km}$. Subsequently, we use all reprojected tiles to compose an Arctic mosaic of the MODIS wavelength bands 1: 459-479 nm, 3: 620$670 \mathrm{~nm}$, and 4: $841-876 \mathrm{~nm}$. We apply a spectral unmixing approach to classify the fractions of open water (between the ice floes), melt ponds, and sea ice, which can be barren or snow covered. For this we use typical reflectance values of these surface types in the above-mentioned wavelength bands (Tschudi et al., 2008). The methodology is explained in more detail together with validation results in Rösel et al. (2012a), and yields the distribution of the fractions of open water, melt ponds, and net sea-ice surface fraction at $0.5 \mathrm{~km}$ grid reso- 
lution. We average these distributions onto a NSIDC polarstereographic grid with $12.5 \mathrm{~km}$ grid resolution. Together with the above-mentioned fractions the standard deviation of the melt-pond fraction per grid cell and the number of clearsky $0.5 \mathrm{~km}$ grid cells contributing to each $12.5 \mathrm{~km}$ grid cell are stored in netCDF file format. The number of clear-sky grid cells is taken as a measure of the cloud fraction later. The grid resolution of $12.5 \mathrm{~km}$ is chosen in accordance to the 8-day melt-pond fraction data set derived with the same approach but using 8-day composite MODIS reflectance data for the years 2000-2011 (Rösel et al., 2012a). We compute the MODIS sea-ice concentration by subtracting the openwater fraction from $100 \%$; note that the MODIS sea-ice concentration includes the sea ice covered by melt ponds, while the net sea-ice surface fraction does not. Open-water fraction, melt-pond fraction, and net sea-ice surface fraction add up to $100 \%$. For the comparison with the microwave brightness temperatures (Sect. 2.2) and sea-ice concentrations derived from them (Sect. 2.3), we average the MODIS sea-ice parameter data set to $100 \mathrm{~km} \times 100 \mathrm{~km}$ grid resolution. In addition, in order to mitigate the influence by variations in the actual sea-ice concentration on our results, we only use grid cells with MODIS sea-ice concentration $>90 \%$ unless stated otherwise. Throughout the paper we use the term "icesurface fraction" for the net sea-ice surface fraction.

\subsubsection{Quality assessment of the MODIS sea-ice parameters}

The quality of MODIS reflectance measurements carried out at high latitudes may be degraded from high sun zenith angles, long pathways through the atmosphere, cloud shadows, and, in addition, shadows caused by ridges in the sea-ice cover. We use only reflectance values with the highest quality. This ensures that cloudy pixels and pixels with cloud shadows, pixels with sun zenith angles $>85^{\circ}$ and pixels with sensor viewing angles $>60^{\circ}$, data from faulty or poorly corrected L1B pixels, pixels containing the default or the highest aerosol level and pixels without any correction for the atmospheric influence are not used.

Mäkynen et al. (2014) hypothesized that our daily MODIS melt-pond fractions are positively biased by about $5-10 \%$ during early melt. In situ observations carried out north of Greenland revealed a melt-pond fraction of $0 \%$ and a sea-ice concentration of $100 \%$ during the first 2 weeks of June 2009 (Mäkynen et al., 2014). Melt onset dates given in Perovich et al. (2014) support this observation. In order to confirm this notion, we derived histograms of the MODIS melt-pond fraction and the MODIS sea-ice concentration using the data with $12.5 \mathrm{~km}$ grid resolution for latitudes north of $83^{\circ} \mathrm{N}$ for all days before $7,9,11$, and 13 June, respectively (Fig. 2). MODIS melt-pond fractions peak at $8 \%$. There are no grid cells with a melt-pond fraction below $4 \%$. The MODIS sea-ice concentration peaks at $98 \%$ without any grid cell with values $>98 \%$, suggesting a bias of $2 \%$. We
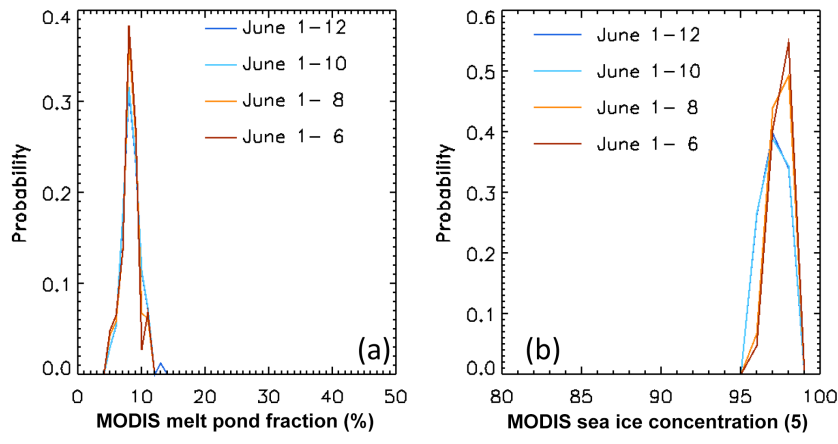

Figure 2. Histograms of MODIS melt-pond fraction (a) and MODIS sea-ice concentration (b) derived when sea-ice cover was near $100 \%$ and melt ponds were not yet present (see text for details) for the first 7, 9, 11, and 13 days of June 2009.

can also confirm the magnitudes of the above-mentioned biases from version 01 of the 8-day MODIS melt-pond fraction product (Kern et al., 2015), and conclude the presence of a systematic bias. Therefore we apply a bias correction and subtract $8 \%$ from the melt-pond fractions and add $2 \%$ to MODIS sea-ice concentrations. A similar correction $(-8 \%$ and $+3 \%)$ was applied to melt-pond fraction and sea-ice concentration of version 01 of the 8-day MODIS melt-pond fraction product (Rösel et al., 2012a; doi:10.1594/WDCC/MODIS_Arctic_MPF yielding version 02: doi:10.1594/WDCC/MODIS_Arctic_MPF_V02). For the daily product used here, we set the few negative melt-pond fractions resulting from the bias correction to zero.

Even though a state-of-the-art cloud masking scheme has been applied to the MODIS reflectance data before the MODIS sea-ice parameter retrieval (Rösel et al., 2012a), there is still a substantial number of misclassified grid cells. It has been demonstrated that even with a multi-channel instrument such as MODIS, cloud classification is a challenge over bright surfaces such as sea ice or snow (Chan and Comiso, 2013; Karlsson and Dybbroe, 2010). In order to mitigate the influence from misclassifications due to residual clouds, we only use $100 \mathrm{~km}$ grid cells with a cloud cover $<5 \%$. About 15500 grid cells remain for the analysis. We note that for MODIS collection 6 data (we use collection 5), a further improvement of cloud cover properties in the high latitudes is not foreseen (King et al., 2013; Baum et al., 2012). We find that by changing the cloud-cover threshold to $2 \%$ or to $10 \%$ (not shown), the number of co-located grid cells does change but the results shown in Sect. 3 do not. We estimate the average uncertainty in the melt-pond fraction, net seaice surface fraction, and MODIS sea-ice concentration due to cloud-induced misclassifications to $\sim 5 \%$.

The potential misclassification of one of the surface types is more important. The reflectance values used are fixed for the entire summer season and the entire Arctic domain. 
Therefore the MODIS sea-ice parameter retrieval does not account for the spatiotemporal variability in the spectral properties of the melt ponds or the non-ponded sea ice. These spectral properties change as a function of ice type and meltseason duration. The spectral properties of melt ponds on first-year ice are likely to approach those of leads and openings as the melt season progresses, while for melt ponds on multiyear ice these change less due its larger thickness and different internal structure. This could result in an overestimation of the melt-pond fraction relative to the open-water fraction for first-year ice or vice versa because the spectral space between sea ice and water is larger than between melt ponds and open water (leads). Such a misclassification would have, however, no implications for the net sea-ice surface fraction. It would affect only the melt pond or the open-water fraction. Therefore such a misclassification does not likely influence the main results of the present paper, but should be kept in mind when interpreting MODIS sea-ice concentrations (see Sect. 3.2).

Rösel et al. (2012a) report root mean square difference (RMSD) values between MODIS melt-pond fraction and independent melt-pond fraction observations of $4-11 \%$. We compare the MODIS sea-ice concentration with visual shipbased sea-ice concentration observations from seven ship expeditions into the Arctic Ocean, and obtain an average RMSD of (10.3 \pm 3.3$) \%$ (range: 6.0-15.2\%). A comparison of our daily MODIS melt-pond fraction data set with contemporary daily melt-pond fraction estimates based on Envisat MERIS data derived with the approach of Istomina et al. (2015a) revealed a consistent agreement (Marks, 2015). Based on these results we are quite confident that the average uncertainty of the melt-pond fraction is better than $10 \%$ and that the MODIS ice-surface fraction is as accurate as $\sim 5 \%$.

At the time of our analysis and writing, this MODIS product was the best we could have, despite the above-mentioned limitations due to cloud cover and spatiotemporal variation of the ice-type-dependent spectral properties of the summer sea-ice cover. The results of our quality analysis and the results of Marks (2015) confirm that we can take the MODIS sea-ice parameters as kind of the ground truth against which we compare brightness temperatures and sea-ice concentrations in Sects. 3 and 4.

\subsection{Satellite microwave brightness temperatures}

We use brightness temperatures measured by the Advanced Microwave Scanning Radiometer aboard the EOS-TERRA satellite: AMSR-E. The AMSR-E data used are from the 6.9, $10.7,18.7,36.5$, and $89.0 \mathrm{GHz}$ channels, which we abbreviate as $6,10,19,37$, and $89 \mathrm{GHz}$ henceforth. We take the AMSR-E swath data from the AMSR-E/Aqua L2A Global Swath Spatially-Resampled Brightness Temperatures data set, version 2: http://nsidc.org/data/docs/daac/ae_12a_tbs.gd. html (Ashcroft and Wentz, 2013). We resample the brightness temperatures of all channels to the resolution of the
$6 \mathrm{GHz}$ channel, which has a $3 \mathrm{~dB}$ footprint of $43 \mathrm{~km} \times 75 \mathrm{~km}$, and co-locate these to the MODIS sea-ice parameters provided at $100 \mathrm{~km}$ grid resolution (Sect. 2.1). We include data from all AMSR-E passes of the same day as the MODIS data. Only data with footprints of which centers are located within $5 \mathrm{~km}$ of the center of a MODIS sea-ice parameter grid cell are used. AMSR-E sampling is approximately every $10 \mathrm{~km}$ so this gives us approximately one data point from each AMSRE pass.

\subsection{Sea-ice concentration algorithms}

We compute sea-ice concentrations from this set of colocated AMSR-E brightness temperatures (Sect. 2.2) using eight selected sea-ice concentration algorithms investigated in the European Space Agency Climate Change Initiative Sea Ice (SICCI) project. The full suite of sea-ice concentration algorithms used in the SICCI project is documented in the SICCI project reports: PVASR (Ivanova et al., 2013) and ATBD (Ivanova et al., 2014), together with the tie points for open water and sea ice. The tie points represent winter conditions. The motivation for this is twofold. One is our wish to intercompare the eight algorithms independently of individual tie points being specifically selected in the original algorithms. We want to use one universal set of tie points (see also Ivanova et al., 2015). This implies the second reason as to why we use winter tie points in the present study. For the derivation of the sea-ice tie points, Ivanova et al. (2015) used high ice concentration areas of convergent ice motion during winter. This ensures that (i) the areas from which tie points are retrieved are large enough and (ii) the areas have indeed $100 \%$ sea-ice concentration. Such an approach does not work under summer conditions because openings/leads in the ice cover do not freeze over. In the present study we focus on a selected number of different (representative) types of algorithms (Ivanova et al., 2015), and do not include algorithms where a methodology is duplicated. The selected algorithms are summarized in Table 4.

We categorize the algorithms into four types based on the way brightness temperatures are used: (1) algorithms based on one polarization and one frequency (e.g., One_channel $6 \mathrm{H}$ ); (2) algorithms based on different frequencies but with the same polarization, such as the frequency mode of the Comiso bootstrap algorithm (Bootstrap_f); (3) algorithms based on different polarizations but with the same frequency, such as the polarization mode of the Comiso bootstrap algorithm (Bootstrap_p); (4) algorithms based on at least two frequencies and/or polarizations, like the NASA Team algorithm (NASA_Team).

A fifth type of algorithms is given by the so-called hybrid algorithms. These combine two or more of the above-mentioned types of algorithms, such as the EUMETSAT OSI-SAF algorithm (Eastwood et al., 2012) or SICCI (Ivanova et al., 2015), which combine Bristol and Bootstrap_f or CalVal, which is identical to Bootstrap_f, and the 
Table 4. The sea-ice concentration algorithms. * Analysis not shown in this study.

\begin{tabular}{llll}
\hline Algorithm & Acronym & Reference & Frequencies/combination \\
\hline Bootstrap_p & BP & Comiso (1986) & 37V, 37H \\
Bootstrap_f/CalVal & BF & Comiso (1986) & 19V, 37V \\
Bristol & BR & Smith (1996) & $19 \mathrm{~V}, 37 \mathrm{~V}, 37 \mathrm{H}$ \\
NASA Team & NT & Cavalieri et al. (1984) & $19 \mathrm{~V}, 19 \mathrm{H}, 37 \mathrm{~V}$ \\
ASI & ASI & Kaleschke et al. (2001), Spreen et al. (2008) & $85 \mathrm{~V}, 85 \mathrm{H}$ \\
Near 90GHz linear & N90 & Ivanova et al. (2014) & $85 \mathrm{~V}, 85 \mathrm{H}$ \\
One_channel (6H) & $6 \mathrm{H}$ & Pedersen (1994) & $6 \mathrm{H}$ \\
NASA Team 2 & NT2 & Markus and Cavalieri (2000) & $19 \mathrm{~V}, 19 \mathrm{H}, 37 \mathrm{~V}, 85 \mathrm{~V}, 85 \mathrm{H}$ \\
Eumetsat OSI-SAF* & $?$ & Eastwood et al. (2012) & Bristol, Bootstrap_f \\
SICCI* & $?$ & Ivanova et al. (2015) & Bristol, Bootstrap_f \\
Arctic Bootstrap* & $?$ & Comiso et al. (1997), Comiso (2009) & Bootstrap_f, Bootstrap_p \\
\hline
\end{tabular}

Arctic version of the Comiso bootstrap algorithm (Comiso et al., 1997; Comiso, 2009), which combines Bootstrap_f and Bootstrap_p. For the high sea-ice concentrations we focus on in this paper, these two hybrid algorithms are almost identical to the algorithm that is employed at high sea-ice concentrations; this is Bristol in the case of the OSI-SAF (zero weight at $<40 \%$, full weight at $\geq 80 \%$ ) and SICCI (zero weight at $<70 \%$, full weight at $\geq 90 \%$ ) algorithms, and Bootstrap_p in the case of the Comiso bootstrap algorithm. Therefore we do not show the analysis for the hybrid algorithms in this paper.

\subsection{Sea-ice age data set}

Brightness-temperature changes over Arctic sea ice are different for first-year ice (FYI) and multiyear ice (MYI) (Eppler et al., 1992). In order to separate these two sea-ice types, we use the Arctic sea-ice age data set (Tschudi et al., 2016). This data set is available with weekly temporal resolution, has a grid resolution of $12.5 \mathrm{~km} \times 12.5 \mathrm{~km}$, and is based on sea-ice drift trajectory analysis (Tschudi et al., 2010; Fowler et al., 2003). We prefer this data set over other approaches that are usually limited to the winter period (e.g., Comiso, 2012; Swan and Long, 2012). We co-locate the sea-ice age data set with the MODIS sea-ice parameter data set as follows. For each MODIS data set grid cell, we first find the sea-ice age grid cell of which center has the smallest distance to the center of the MODIS data set grid cell. Secondly, we select a $7 \times 7$ grid cell array around that first co-located grid cell from the sea-ice age data set. Subsequently, we count the numbers with which a certain sea-ice age occurs within the co-located $7 \times 7$ grid cell array, and divide by the total number (for every ice age) of counts. We assign the ice type FYI to the respective MODIS data-set grid cell, only if more than $90 \%$ of the counts indicate a sea-ice age of 1 year. We correspondingly assign the ice type MYI only if more than $90 \%$ of the counts indicate a sea-ice age of 3 years or older. All other grid cells are kept without any classification into an ice type. In our co-located data set, FYI is assigned to MODIS data set grid cells in the northern Chukchi Sea and parts of the central Arctic Ocean as well as north of Franz Josef Land (Fig. 1a). Multiyear ice is assigned to MODIS data set grid cells north of the Canadian Arctic Archipelago (Fig. 1b). The latter region is also the area where the largest number of colocations is found, whereas only few co-locations are found in the northern Chukchi Sea (Fig. 1c).

\section{Results}

\subsection{MODIS sea-ice parameters}

We show the temporal development of the daily sea-ice parameters obtained with MODIS (Sect. 2.1) for June to $\mathrm{Au}-$ gust 2009 in Fig. 3. These include MODIS sea-ice concentration, the net sea-ice surface fraction, the net surface-water fraction, which is the open-water fraction plus the melt-pond fraction, and the melt-pond fraction for each day and each co-located grid cell. No further averaging is applied, and we show all grid cells regardless of ice type. Gaps in the time series and the varying number of data points are caused by daily variations in cloud cover and the decrease in sea-ice cover from June to August. Only grid cells with MODIS seaice concentration $>90 \%$ are shown; the number of grid cells fulfilling this criterion decreases with progressing melt season.

During the first $2-3$ weeks, the MODIS melt-pond fraction in our data set remains near zero. Then the melt-pond fraction starts to increase, first slowly: days 20-30 (fifth and sixth 5-day period or pentad of June), then rapidly: days 3045 (first to third pentad of July). After a short plateau, where the melt-pond fraction remains near $35 \%$, it first declines rapidly to about $20 \%$ at days 55-60 (last pentad of July) and then more slowly to about $15 \%$ until the end of our study period (31 August). Throughout June, MODIS sea-ice concentrations are close to $100 \%$ until day 30, and then there is more variability around $90-95 \%$ after day 55 . Net total water fraction and net sea-ice surface fraction are linked to the previous two parameters and add up to $100 \%$. 


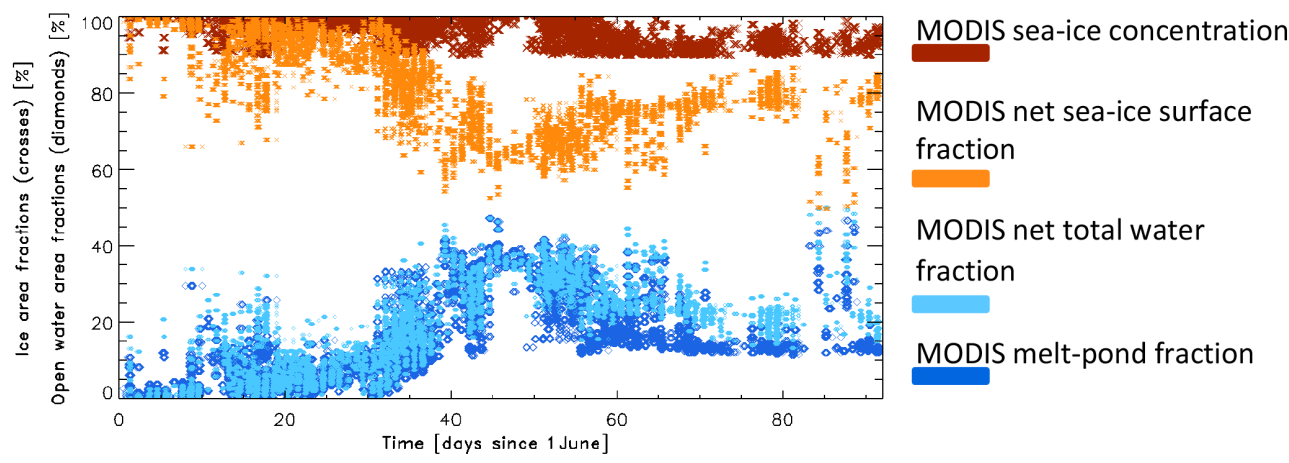

Figure 3. Time series of open-water and sea-ice fractions for all MODIS grid cells used in the present study for 1 June 2009 to 31 August 2009.

Table 5. Statistical parameters of the comparison AMSR-E sea-ice concentration vs. MODIS sea-ice concentration (see Fig. 4) for June 2009. Each column gives the value for all grid cells with MODIS sea-ice concentration $>20 \%$, the multiyear (MYI) ice grid cells, and the first-year ice (FYI) grid cells (see Sect. 2.4). Slopes closest to 1, highest correlations, and lowest RMSD values are noted in bold font. Values obtained for the ASI and NT2 algorithm are shown for completeness but are in italic font.

\begin{tabular}{lcccc}
\hline $\begin{array}{l}\text { June } \\
\text { Algorithm }\end{array}$ & $\begin{array}{c}\text { Slope } \\
\text { All; FYI; MYI }\end{array}$ & $\begin{array}{c}\text { Correlation } \\
\text { All; FYI; MYI }\end{array}$ & $\begin{array}{c}\text { RMSD } \\
\text { All; FYI MYI }\end{array}$ & $\begin{array}{c}\text { N } \\
\text { All; FYI; MYI }\end{array}$ \\
\hline 6H & $1.16 ; 1.16 ; 1.19$ & $\mathbf{0 . 8 6} ; \mathbf{0 . 8 9} ;-0.28$ & $17.1 ; 16.6 ; 18.8$ & $6272 ; 1127 ; 649$ \\
ASI & $1.03 ; 1.05 ; 1.04$ & $0.81 ; 0.86 ;-0.10$ & $7.7 ; 10.3 ; 4.4$ & - \\
Bootstrap_f & $1.27 ; 1.28 ; 1.28$ & $0.72 ; 0.86 ;-0.50$ & $27.9 ; 27.7 ; 30.2$ & - \\
Bootstrap_p & $0.92 ; 0.92 ; 0.97$ & $0.62 ; 0.71 ;-0.01$ & $13.9 ; 15.3 ; 9.0$ & - \\
Bristol & $1.14 ; 1.15 ; 1.16$ & $0.75 ; 0.86 ;-0.42$ & $16.3 ; 16.6 ; 18.6$ & - \\
NASA Team & $\mathbf{1 . 0 0} \mathbf{1 . 0 1} ; \mathbf{1 . 0 1}$ & $0.71 ; 0.73 ; \mathbf{0 . 3 2}$ & $\mathbf{8 . 9} ; \mathbf{1 1 . 7} \mathbf{6 . 3}$ & - \\
Near90_lin & $1.02 ; 1.03 ; 1.07$ & $0.68 ; 0.81 ;-0.37$ & $12.2 ; 13.0 ; 11.1$ & - \\
NT2 & $1.02 ; 1.04 ; 1.01$ & $0.69 ; 0.79 ; 0.07$ & $5.3 ; 8.5 ; 2.1$ & - \\
\hline
\end{tabular}

\subsection{AMSR-E sea-ice concentration compared to MODIS sea-ice concentration}

We first compare sea-ice concentrations derived with the algorithms listed in Table 4 from AMSR-E brightness temperatures (Sects. 2.2 and 2.3) with MODIS sea-ice concentrations (Sect. 2.1), with the aim of illustrating how summertime AMSR-E sea-ice concentrations compare to an independent sea-ice concentration estimate. We include all data with MODIS sea-ice concentrations $>20 \%$. We find different agreement between AMSR-E and MODIS sea-ice concentrations for the different algorithms for June (Table 5), July (Fig. 4, Table 6), and August (Table 7) of the year 2009. Common to all algorithms is a cluster of data, which is more or less centered at an AMSR-E sea-ice concentration of $100 \%$. Slopes of a linear regression forced through the point $(0,0)$ range from 0.90 for Bootstrap_p (Fig. 4e) to 1.12 for Bootstrap_f (Fig. 4b). Values of the root mean square difference (RMSD) between AMSR-E and MODIS sea-ice concentrations vary between $7.4 \%$ for NT2 (Fig. 4f) and $18.1 \%$ for Bootstrap_f. Only few values of MODIS sea-ice concentrations $<80 \%$ exist. For these, AMSR-E sea-ice concentrations are generally biased low by between 10 and $20 \%-$ except for the NT2 algorithm (Fig. 4f). The ASI and NT2 algorithms cut off sea-ice concentrations once they exceed 103 and $100 \%$ ice concentration, respectively. We therefore exclude these two algorithms from the following quality ranking.

We take the slope (the closer to 1 the better), the correlation (the higher the better), and the RMSD (the lower the better) as a quality measure and find the NASA Team algorithm to outperform all other algorithms listed in Table 4 for June (Table 5) - no matter whether we use all grid cells or only FYI or MYI grid cells (see Sect. 2.4). For July (Table 6), the NASA Team algorithm is as good as the Near90_lin algorithm. For August (Table 7), best slopes are obtained for the Bootstrap_p algorithm, while lowest RMSD values are obtained for the NASA Team algorithm. Note that the number of FYI grid cells is extremely low for August and that the numbers given in Table 7 for FYI should not be overinterpreted.

The average correlation, computed from six algorithms, decreases from June: $0.72 \pm 0.07$ to $0.53 \pm 0.18$ in July, to $0.42 \pm 0.10$ in August. We believe this could be attributed to the known limitations of AMSR-E and other passive microwave sea-ice concentration retrieval algorithms during 

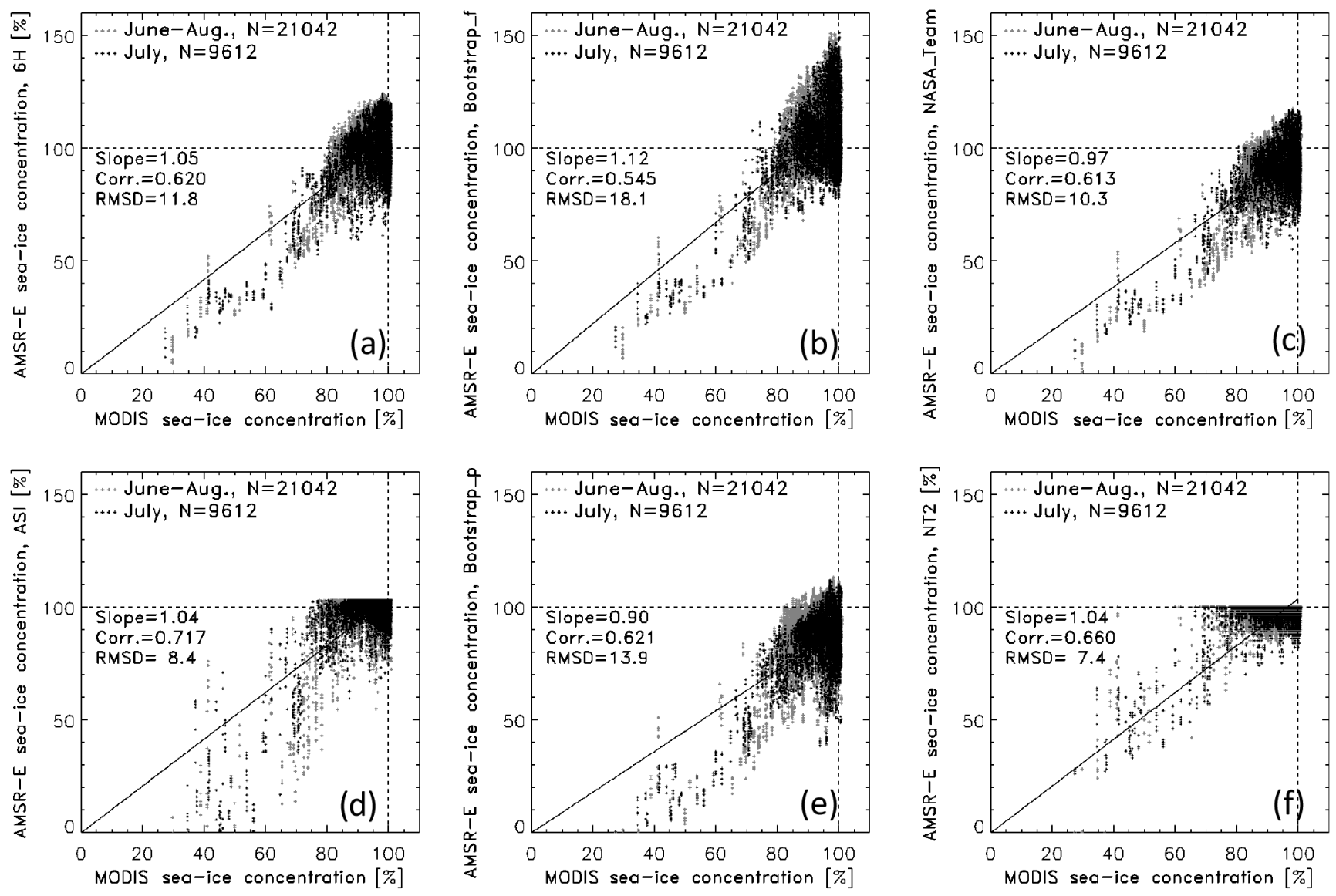

Figure 4. AMSR-E sea-ice concentration computed with six of the eight algorithms listed in Table 2 vs. MODIS sea-ice concentration for all grid cells with MODIS sea-ice concentration $>20 \%$ and cloud fraction $<5 \%$. Gray and black symbols denote data from the entire period and July only, respectively. The black line denotes a linear regression of the sea-ice concentrations of July forced through $(0,0)$ with the slope as given in each image. The linear correlation coefficient and root mean square difference for sea-ice concentrations of July are denoted by "Corr." and "RMSD”. Slope, Corr, and RMSD for June, July (this figure), and August are summarized in Tables 5-7.

Table 6. Statistical parameters of the comparison AMSR-E sea-ice concentration vs. MODIS sea-ice concentration (see Fig. 4) for July 2009. Each column gives the value for all grid cells with MODIS sea-ice concentration $>20 \%$, the multiyear (MYI) ice grid cells, and the first-year ice (FYI) grid cells (see Sect. 2.4). Slopes closest to 1, highest correlations, and lowest RMSD values are noted in bold font. Values obtained for the ASI and NT2 algorithm are shown for completeness but are in italic font.

\begin{tabular}{lcccc}
\hline $\begin{array}{l}\text { July } \\
\text { Algorithm }\end{array}$ & $\begin{array}{c}\text { Slope } \\
\text { All; FYI; MYI }\end{array}$ & $\begin{array}{c}\text { Correlation } \\
\text { All; FYI; MYI }\end{array}$ & $\begin{array}{c}\text { RMSD } \\
\text { All; FYI; MYI }\end{array}$ & $\begin{array}{c}N \\
\text { All; FYI; MYI }\end{array}$ \\
\hline 6H & $1.05 ; 1.08 ; 1.05$ & $0.62 ; 0.81 ;-0.03$ & $11.8 ; 12.4 ; 11.9$ & $9612 ; 967 ; 634$ \\
ASI & $1.04 ; 1.09 ; 1.04$ & $0.72 ; 0.83 ;-0.05$ & $8.4 ; 11.8 ; 6.6$ & - \\
Bootstrap_f & $1.12 ; 1.16 ; 1.13$ & $0.55 ; 0.78 ; 0.14$ & $18.1 ; 17.7 ; 20.1$ & - \\
Bootstrap_p & $0.90 ; 0.94 ; 0.90$ & $0.62 ; \mathbf{0 . 8 5} ;-0.22$ & $13.9 ; 9.9 ; 14.4$ & - \\
Bristol & $1.04 ; 1.08 ; 1.05$ & $0.62 ; \mathbf{0 . 8 5} ; 0.05$ & $11.7 ; 10.8 ; 12.0$ & - \\
NASA Team & $0.97 ; \mathbf{1 . 0 0} ; 0.97$ & $0.13 ; 0.80 ;-0.16$ & $\mathbf{1 0 . 3} ; \mathbf{8 . 9} ; 10.4$ & - \\
Near90_lin & $\mathbf{0 . 9 8} ; 1.03 ; \mathbf{1 . 0 0}$ & $\mathbf{0 . 6 3} 0.82 ; 0.04$ & $10.7 ; 10.9 ; \mathbf{7 . 3}$ & - \\
NT2 & $1.04 ; 1.10 ; 1.02$ & $0.66 ; 0.74 ;-0.03$ & $7.4 ; 12.1 ; 5.7$ & - \\
\hline
\end{tabular}

melting conditions due to varying snow properties and due to melt ponds. It is difficult to quantify the sensitivity of such algorithms to snow-property variations because their magni- tude and spatiotemporal distribution is unknown. In contrast, it should be possible to quantify the sensitivity of such algorithms to melt ponds because these should theoretically 
Table 7. Statistical parameters of the comparison AMSR-E sea-ice concentration vs. MODIS sea-ice concentration (see Fig. 4) for August 2009. Each column gives the value for all grid cells with MODIS sea-ice concentration $>20 \%$, the multiyear (MYI) ice grid cells, and the first-year ice (FYI) grid cells (see Sect. 2.4). Slopes closest to 1, highest correlations, and lowest RMSD values are noted in bold font. Values obtained for the ASI and NT2 algorithm are shown for completeness but are in italic font.

\begin{tabular}{lcccc}
\hline $\begin{array}{l}\text { August } \\
\text { Algorithm }\end{array}$ & $\begin{array}{c}\text { Slope } \\
\text { All; FYI; MYI }\end{array}$ & $\begin{array}{c}\text { Correlation } \\
\text { All; FYI; MYI }\end{array}$ & $\begin{array}{c}\text { RMSD } \\
\text { All; FYI; MYI }\end{array}$ & $\begin{array}{c}N \\
\text { All; FYI; MYI }\end{array}$ \\
\hline 6H & $1.08 ; \mathbf{1 . 0 3} ; 1.11$ & $0.48 ; \mathbf{0 . 6 2} ; 0.22$ & $10.0 ; 8.1 ; 11.0$ & $5158 ; 162 ; 505$ \\
ASI & $1.13 ; 1.15 ; 1.14$ & $0.55 ; 0.37 ; 0.25$ & $12.5 ; 14.2 ; 13.0$ & - \\
Bootstrap_f & $1.16 ; 1.15 ; 1.19$ & $0.30 ; 0.49 ; 0.18$ & $17.7 ; 15.4 ; 19.1$ & - \\
Bootstrap_p & $\mathbf{1 . 0 0} ; 0.95 ; \mathbf{1 . 0 3}$ & $0.27 ; 0.54 ; \mathbf{0 . 4 4}$ & $17.0 ; 8.8 ; \mathbf{6 . 2}$ & - \\
Bristol & $1.10 ; 1.07 ; 1.13$ & $0.46 ; 0.57 ; 0.35$ & $12.0 ; 9.5 ; 12.8$ & - \\
NASA Team & $1.03 ; 0.95 ; 1.06$ & $0.48 ; 0.53 ; 0.31$ & $\mathbf{7 . 9} ; \mathbf{8 . 5} ; 8.1$ & - \\
Near90_lin & $1.10 ; 1.07 ; 1.11$ & $\mathbf{0 . 5 4} ; 0.35 ; 0.37$ & $11.2 ; 11.2 ; 11.4$ & - \\
NT2 & $1.10 ; 1.14 ; 1.11$ & $0.19 ; 0.15 ; 0.08$ & $10.6 ; 13.8 ; 10.5$ & - \\
\hline
\end{tabular}

be detected as open water. Consequently, such algorithms should provide an open-water fraction which is the sum of the fractions of leads and openings between the ice floes and of the melt ponds on the sea ice. In order to isolate the influence of the melt ponds, one needs to investigate the high ice concentration areas separately. The MODIS sea-ice parameter data set (Sect. 2.1), which we use, is ideal for this purpose because it provides the open-water fraction (in leads and openings), the melt-pond fraction (on sea ice) and the net seaice surface fraction. By limiting our investigation to MODIS sea-ice concentrations $>90 \%$, we can take the MODIS icesurface fraction as an inverse measure of the melt-pond fraction.

\subsection{AMSR-E sea-ice concentration compared to MODIS ice-surface fraction}

We compare AMSR-E sea-ice concentration (Sect. 3.2) with the MODIS ice-surface fraction (Sect. 2.1) for grid cells with MODIS sea-ice concentration $>90 \%$. For the range of observed MODIS ice-surface fractions between about 50 and $100 \%$, we find quite different ranges of AMSR-E sea-ice concentrations (Fig. 5). For the Bootstrap_f and 6H algorithm, AMSR-E sea-ice concentrations range between 80 and $150 \%$ and 75 and $125 \%$, respectively, and suggest a relatively well-defined linear relationship (Fig. 5a, b). For July, we find a slope between AMSR-E sea-ice concentration and MODIS ice-surface fraction of 1.44 and 1.34, respectively. The respective correlation coefficients are 0.855 and 0.820 . For the Bootstrap_p and NASA_Team algorithm, AMSR-E sea-ice concentrations tend to cluster in a point cloud with a shallower slope and a less well-defined linear relationship (Fig. 5c, e). For July, the corresponding slopes are 1.14 and 1.23 , respectively, and the respective correlation coefficients are 0.428 and 0.666. AMSR-E sea-ice concentrations derived with the ASI and the NT2 algorithm stay between 75 and $100 \%$ and between 85 and $100 \%$, respectively (Fig. 5d, f); the small range in AMSR-E sea-ice concentrations of these two algorithms can clearly be attributed to the cutoff mentioned in Sect. 3.2.

We obtain slope, correlation coefficient, and RMSD values of all eight algorithms (see Table 4) separately for (i) all grid cells, (ii) only the FYI grid cells, and (iii) only the MYI grid cells (see Sect. 2.4), and summarize these in Tables 8-10 for June, July, and August. For August we exclude all values obtained for FYI grid cells because of their low count of 44 (Table 10). We find an increase in the slopes from June to July for all algorithms, which is followed by a decrease for $6 \mathrm{H}$, Bootstrap_f and Bristol algorithms but a further increase for Bootstrap_p and Near90_lin algorithms from July to August. Correlations between AMSR-E sea-ice concentrations and MODIS ice-surface fractions are below 0.4 in June (Table 8). In contrast, for July (Table 9) we obtain correlations $>0.8$ for $6 \mathrm{H}$, Bootstrap_f, and Bristol algorithms - together with the largest slopes. These suggest a considerable sensitivity of these algorithms to the melt-pond fraction. This does also apply to MYI grid cells. For July, the lowest correlation of 0.43 is obtained for the Bootstrap_p algorithm - together with the smallest slope (Table 9). This suggests the weakest sensitivity to the melt-pond fraction among the investigated algorithms.

We carried out the same intercomparison using a MODIS sea-ice concentration threshold of $98 \%$ (not shown) instead of $90 \%$. By using $98 \%$, no results can be obtained for August because of too few valid data. For June and July, slopes remain similar to those in Tables 8 and 9. For June, correlations are considerably smaller compared to using $90 \%$. Correlations are a bit higher for July. Despite this better correlation in July, the peak melting period (see Fig. 3), we decided to keep the $90 \%$ threshold to ensure a large enough number of data points. The results of the previous paragraph remain the same for 90 and $98 \%$ MODIS sea-ice concentration threshold.

We conclude the following: for one type of algorithm, AMSR-E sea-ice concentration is linearly related to the MODIS ice-surface fraction, as we hypothesized in the in- 
Table 8. Statistical parameters of the comparison AMSR-E sea-ice concentration vs. MODIS ice-surface fraction for MODIS sea-ice concentration $>90 \%$ (see Fig. 5) for June 2009. Each column gives the value for all grid cells with MODIS sea-ice concentration $>90 \%$, and the respective multiyear (MYI) and first-year ice (FYI) grid cells. Values obtained for the ASI and NT2 algorithm are shown for completeness but are in italic font.

\begin{tabular}{lcccc}
\hline $\begin{array}{l}\text { June } \\
\text { Algorithm }\end{array}$ & $\begin{array}{c}\text { Slope } \\
\text { All; FYI; MYI }\end{array}$ & $\begin{array}{c}\text { Correlation } \\
\text { All; FYI; MYI }\end{array}$ & $\begin{array}{c}\text { RMSD } \\
\text { All; FYI; MYI }\end{array}$ & \begin{tabular}{c} 
All; FYI; MYI \\
\hline 6H
\end{tabular} \\
ASI & $1.23 ; 1.28 ; 1.22$ & $0.40 ; 0.33 ;-0.14$ & $22.6 ; 25.9 ; 21.9$ & $5821 ; 916 ; 649$ \\
Bootstrap_f & $1.34 ; 1.43 ; 1.32$ & $0.10 ; 0.36 ;-0.38$ & $33.8 ; 38.3 ; 33.4$ & - \\
Bootstrap_p & $0.97 ; 1.02 ; 1.00$ & $0.09 ;-0.10 ; 0.02$ & $11.8 ; 13.9 ; 8.8$ & - \\
Bristol & $1.20 ; 1.28 ; 1.20$ & $0.12 ; 0.22 ;-0.31$ & $21.5 ; 25.8 ; 21.7$ & - \\
NASA Team & $1.06 ; 1.11 ; 1.04$ & $0.15 ;-0.15 ; 0.31$ & $10.8 ; 16.0 ; 7.3$ & - \\
Near90_lin & $1.08 ; 1.15 ; 1.10$ & $0.09 ; 0.05 ;-0.28$ & $13.8 ; 17.1 ; 13.8$ & - \\
NT2 & $1.07 ; 1.14 ; 1.04$ & $0.07 ;-0.08 ; 0.06$ & $8.9 ; 14.2 ; 5.1$ & - \\
\hline
\end{tabular}

Table 9. Statistical parameters of the comparison AMSR-E sea-ice concentration vs. MODIS ice-surface fraction for MODIS sea-ice concentration $>90 \%$ (see Fig. 5) for July 2009. Each column gives the value for all grid cells with MODIS sea-ice concentration $>90 \%$, and the respective multiyear (MYI) and first-year ice (FYI) grid cells. Values obtained for the ASI and NT2 algorithm are shown for completeness but are in italic font.

\begin{tabular}{lcccc}
\hline $\begin{array}{l}\text { July } \\
\text { Algorithm }\end{array}$ & $\begin{array}{c}\text { Slope } \\
\text { All; FYI } ; \text { MYI }\end{array}$ & $\begin{array}{c}\text { Correlation } \\
\text { All; FYI } ; \text { MYI }\end{array}$ & $\begin{array}{c}\text { RMSD } \\
\text { All; FYI; MYI }\end{array}$ & \begin{tabular}{c} 
All; FYI; MYI \\
\hline 6H
\end{tabular} \\
ASI & $1.34 ; 1.33 ; 1.33$ & $0.82 ; 0.56 ; 0.84$ & $26.8 ; 26.9 ; 26.5$ & $7572 ; 491 ; 539$ \\
Bootstrap_f & $1.44 ; 1.42 ; 1.45$ & $0.86 ; 0.65 ; 0.91$ & $34.1 ; 33.7 ; 35.1$ & - \\
Bootstrap_p & $1.14 ; 1.15 ; 1.11$ & $0.43 ; 0.15 ; 0.02$ & $15.9 ; 15.9 ; 17.8$ & - \\
Bristol & $1.33 ; 1.32 ; 1.32$ & $0.85 ; 0.65 ; 0.85$ & $25.9 ; 25.8 ; 26.1$ & - \\
NASA Team & $1.23 ; 1.21 ; 1.21$ & $0.67 ; 0.26 ; 0.57$ & $19.9 ; 19.4 ; 19.8$ & - \\
Near90_lin & $1.24 ; 1.26 ; 1.24$ & $0.54 ; 0.33 ; 0.41$ & $21.4 ; 22.6 ; 22.3$ & - \\
NT2 & $1.29 ; 1.28 ; 1.26$ & $0.38 ; 0.36 ; 0.38$ & $25.3 ; 23.7 ; 24.3$ & - \\
\hline
\end{tabular}

Table 10. Statistical parameters of the comparison AMSR-E sea-ice concentration vs. MODIS ice-surface fraction for MODIS sea-ice concentration $>90 \%$ (see Fig. 5) for August 2009. Each column gives the value for all grid cells with MODIS sea-ice concentration $>90 \%$, and the respective multiyear (MYI) and first-year ice (FYI) grid cells. Values obtained for the ASI and NT2 algorithm are shown for completeness but are in italic font.

\begin{tabular}{lcccc}
\hline $\begin{array}{l}\text { August } \\
\text { Algorithm }\end{array}$ & $\begin{array}{c}\text { Slope } \\
\text { All; FYI; MYI }\end{array}$ & $\begin{array}{c}\text { Correlation } \\
\text { All; FYI; MYI }\end{array}$ & $\begin{array}{c}\text { RMSD } \\
\text { All; FYI; MYI }\end{array}$ & $\begin{array}{c}N \\
\text { All; FYI; MYI }\end{array}$ \\
\hline 6H & $1.28 ;-; 1.30$ & $0.39 ;-; 0.28$ & $23.1 ;-; 24.2$ & $2091 ; 44 ; 207$ \\
ASI & $1.33 ;-; 1.33$ & $0.50 ;-; 0.65$ & $26.8 ;-; 26.5$ & - \\
Bootstrap_f & $1.36 ;-; 1.39$ & $0.19 ;-; 0.19$ & $30.3 ;-; 31.8$ & - \\
Bootstrap_p & $1.21 ;-; 1.25$ & $0.14 ;-; 0.79$ & $29.8 ;-; 19.4$ & - \\
Bristol & $1.31 ;-; 1.34$ & $0.41 ;-; 0.51$ & $25.3 ;-; 26.9$ & - \\
NASA Team & $1.23 ;-; 1.26$ & $0.49 ;-; 0.70$ & $19.0 ;-; 21.0$ & - \\
Near90_lin & $1.32 ;-; 1.33$ & $0.54 ;-; 0.68$ & $25.4 ;-; 25.8$ & - \\
NT2 & $1.29 ;-; 1.29$ & $0.18 ;-;-0.14$ & $23.7 ;-; 23.6$ & - \\
\hline
\end{tabular}

troduction; i.e., AMSR-E sea-ice concentrations are sensitive to the melt-pond fraction. These are the 6H, Bootstrap_f, and Bristol algorithms. For the other algorithms investigated, such a linear relationship is increasingly less pronounced in the following descending order: NASA Team, Near90_lin, Bootstrap_p.

\section{Discussion}

\subsection{Sea-ice concentration algorithm parameter space}

To explain the different sensitivities to the melt pond fraction (Sect. 3.2), we start with an illustration of the distribu- 

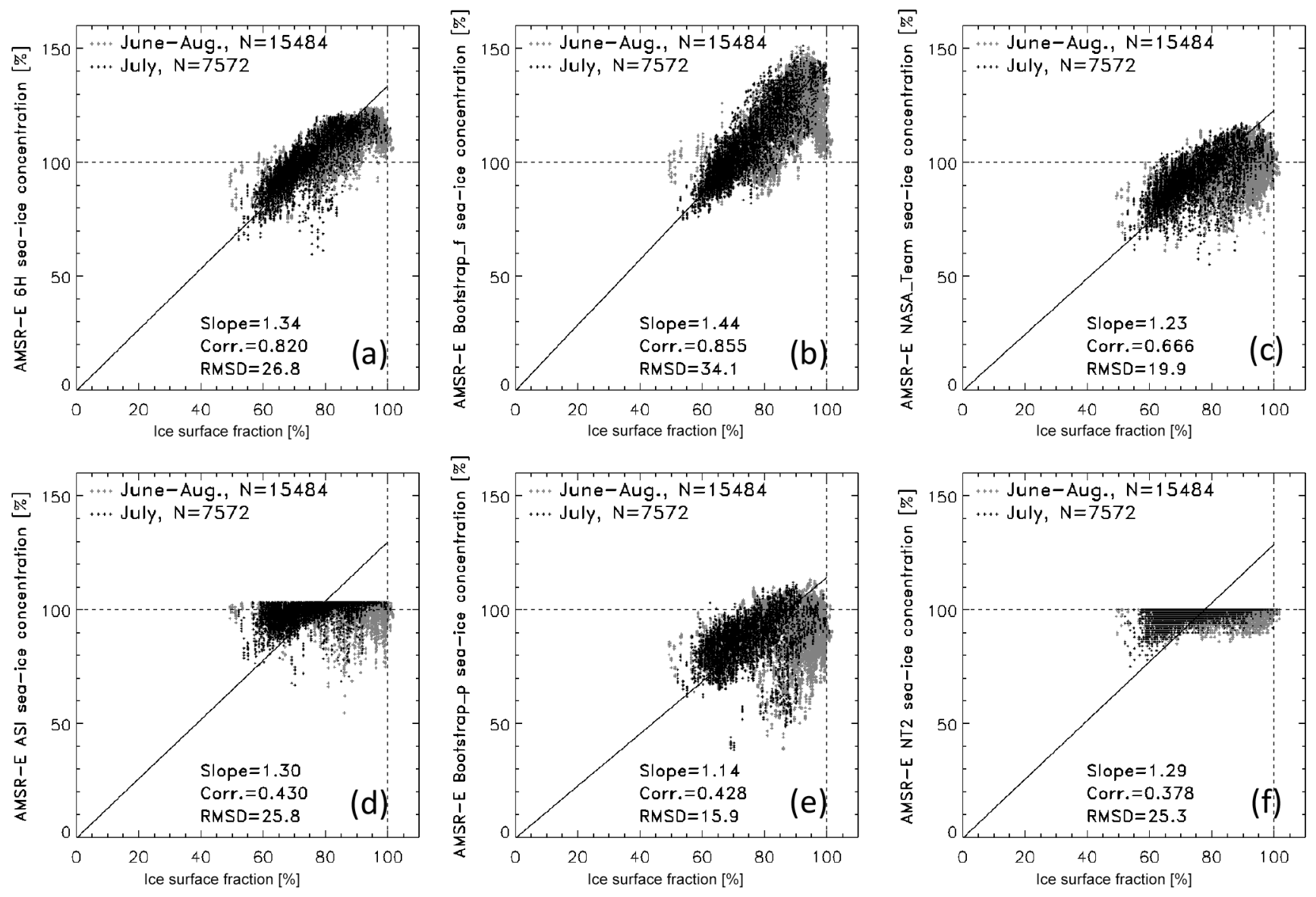

Figure 5. AMSR-E sea-ice concentration computed with six of the eight algorithms listed in Table 2 vs. MODIS ice-surface fraction for all grid cells with MODIS sea-ice concentration $>90 \%$ and cloud fraction $<5 \%$. Gray and black symbols denote data from the entire period and July only, respectively. The black line denotes a linear regression of the sea-ice concentrations of July forced through $(0,0)$ with the slope as given in the each image. The linear correlation coefficient and root mean square difference for sea-ice concentrations of July are denoted by "Corr." and "RMSD”. Slope, Corr, and RMSD for June, July (this figure), and August are summarized in Tables 8-10.

tion of AMSR-E brightness temperatures and contemporary MODIS ice-surface fractions of July 2009 in the parameter spaces of four of the algorithms (Fig. 6). These algorithms are NASA Team, ASI, or Near90_lin, as both rely on brightness temperatures near $90 \mathrm{GHz}$, and the two bootstrap algorithms. Bootstrap_f and Bootstrap_p are the two algorithms with the highest and the lowest sensitivity of AMSR-E seaice concentrations to melt-pond fraction, respectively (Fig. 5, Tables $8,9,10)$. The NASA Team algorithm is among the most used ones and the ASI and Near90_lin algorithm have the advantage of a substantially finer grid resolution thanks to using the near $90 \mathrm{GHz}$ channels. In every parameter space we show the following items.

I. A wintertime AMSR-E brightness-temperature distribution is shown for open water (black dots) and AMSRE NT2 sea-ice concentration $>90 \%$ (white dots). The spread of the black dots results from the weather influence over open water. We refer to these as winter data points or winter brightness temperatures in the following text.

II. Wintertime open-water (white cross) and sea-ice (black crosses) tie points obtained from Ivanova et al. (2015) and used to compute the AMSR-E sea-ice concentration (see Sect. 2.3 for an explanation of why we use winter tie points) are shown.

III. Red arrows denote the direction of increasing sea-ice concentration.

IV. AMSR-E brightness temperatures of our data set, i.e., only for MODIS sea-ice concentration $>90 \%$ for the month of July, color-coded with the contemporary MODIS ice-surface fraction, are shown. We refer to these as summer data points or summer brightness temperatures in the following text.

V. A red line connecting FYI and MYI tie points denotes the ice line. 


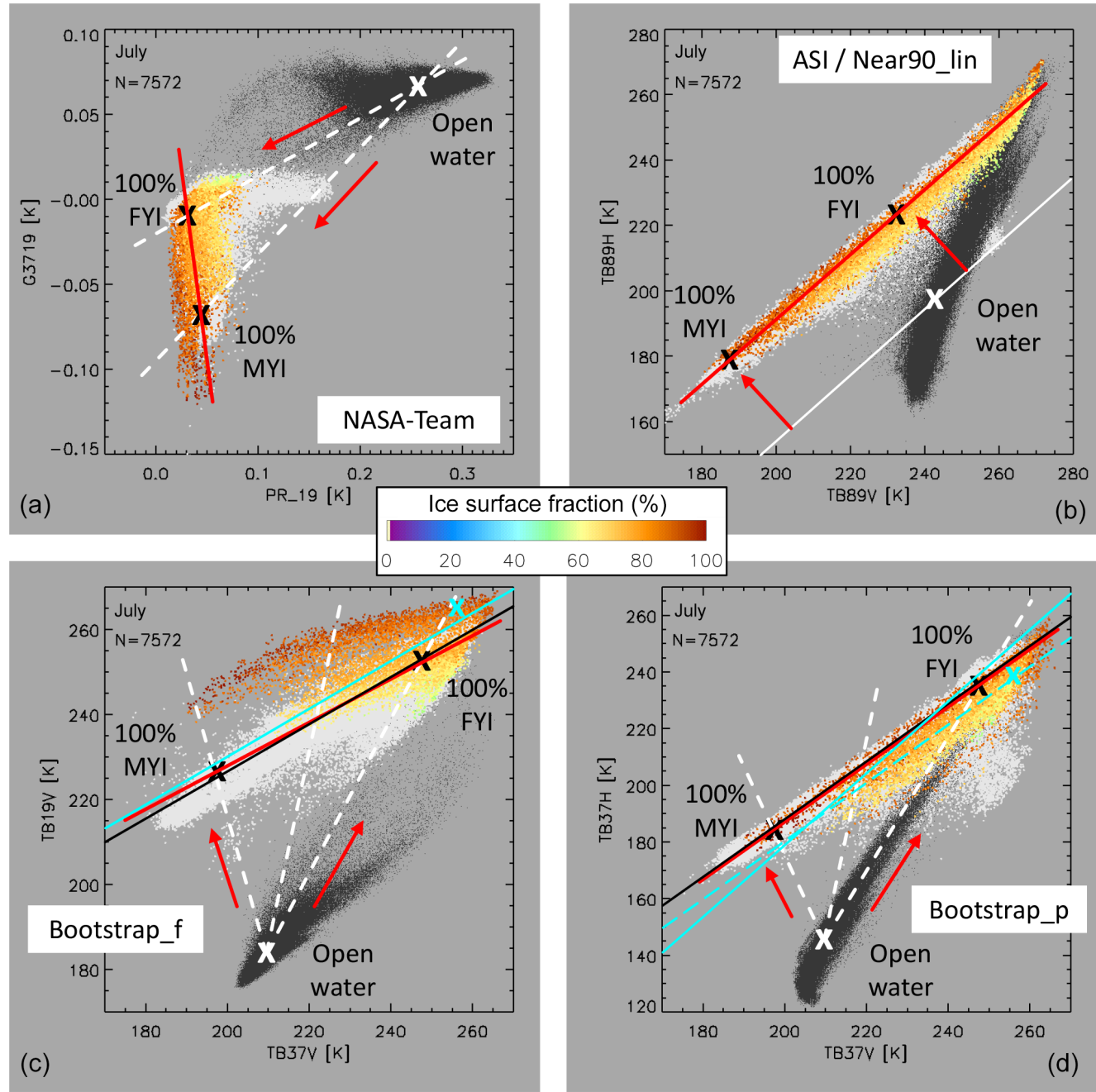

Figure 6. Parameter spaces for NASA Team (a), ASI/Near90_lin (b), Bootstrap_f (c), and Bootstrap_p (d) algorithms. Each image contains AMSR-E brightness-temperature data for the respective space for July 2009, color-coded with the contemporary MODIS ice-surface fraction for cloud cover $<5 \%$ and MODIS sea-ice concentration $>90 \%$. Black and white dots denote winter (10 February 2007) Arctic brightness temperatures for 0 and $>90 \%$ NT2 sea-ice concentration, respectively. White and black crosses denote open-water and sea-ice tie points for winter, respectively (Ivanova et al., 2015). Red arrows show the direction of the sea-ice concentration increase. Red lines connect first-year ice (FYI) and multiyear ice (MYI) tie points, and are referred to as ice lines in the text. For white, black, and cyan lines and crosses, see text in Sect. 4.2.

\subsubsection{NASA Team algorithm}

For the NASA Team algorithm (Fig. 6a), summer data points from July 2009 are located well within the cloud of winter data points (see I). The NASA Team tie-point triangle (Cavalieri et al., 1990) is approximated by the dashed white lines and the red (ice) line (see V). Many summer data points are located to the left of the ice line. For these data points, NASA Team sea-ice concentrations exceed $100 \%$, and MODIS icesurface fractions are between 80 and $100 \%$ (see the color scale). To the right of the ice line, summer data points coincide with MODIS ice-surface fractions of $\sim 70 \%$, and are supposed to provide NASA Team sea-ice concentrations between 80 and $100 \%$ (compare Fig. 5c).

\subsubsection{ASI or Near90_lin algorithm}

For the ASI or Near90_lin algorithm (Fig. 6b) summer data points from July 2009 are also located well within the cloud of winter data points. A considerable number of the summer data points are located above the ice line. For these data points, ASI or Near90_lin sea-ice concentrations exceed $100 \%$. Most of the summer data points located below the ice line correspond to ASI or Near90_lin sea-ice concentrations between 80 and $100 \%$. The associated MODIS ice-surface fractions decrease from $\sim 100 \%$ close to the MYI tie point 
Table 11. Top row: winter tie points for first-year ice (FYI) and multiyear ice (MYI) expressed as normalized brightness-temperature polarization difference (PR); other rows: summer tie points derived as outlined in the text expressed as PR and brightness temperature (TB) at vertical (TBV) and horizontal (TBH) polarization. Brightness temperatures are given together with 1 standard deviation.

\begin{tabular}{lccc}
\hline Frequency & $19 \mathrm{GHz}$ & $37 \mathrm{GHz}$ & $89 \mathrm{GHz}$ \\
\hline PR (winter, FYI; MYI) & $0.030 ; 0.043$ & $0.025 ; 0.031$ & $0.021 ; 0.024$ \\
\hline PR (summer) & 0.034 & 0.033 & 0.021 \\
\hline TBH (summer) (K) & $247.6 \pm 6.5$ & $239.0 \pm 4.9$ & $226.3 \pm 10.0$ \\
\hline TBV (summer) (K) & $265.2 \pm 2.5$ & $255.5 \pm 4.5$ & $235.0 \pm 11.8$ \\
\hline
\end{tabular}

to $\sim 70 \%$ when following the summer data points towards the FYI tie point and beyond (compare Fig. 5d).

\subsubsection{Bootstrap_f algorithm}

For the Bootstrap_f algorithm (Fig. 6c), a substantial number of summer data points from July 2009 fall outside the winter data-point cloud. The majority of the summer data points are located above the winter ice line (red: our tie points, black: Comiso et al., 1997). The locations of these data points relative to the open-water tie point, the winter ice lines, and the tie points for MYI and FYI suggests that Bootstrap_f sea-ice concentrations exceed $100 \%$ by up to a few tens of percent (compare Fig. 5b). The distance between the openwater tie point and the winter ice lines increases from left (MYI tie point) to right (FYI tie point). Similar MODIS icesurface fractions tend to intersect the winter ice lines. Therefore, the overestimation of Bootstrap_f sea-ice concentration decreases with decreasing MODIS ice-surface fraction (see also Fig. 5b).

\subsubsection{Bootstrap_p algorithm}

For the Bootstrap_p algorithm (Fig. 6d), only few summer data points from July 2009 are located closely above the winter ice lines (see also Sect. 4.1.3). Consequently, Bootstrap_p sea-ice concentrations do not exceed $110 \%$ (compare Fig. 5e). Similar to the Bootstrap_f algorithm (Fig. 6c) only very few summer data points are located close to the MYI tie point. The majority of those data points which are associated with MODIS ice-surface fractions $\sim 70 \%$ are located in a relatively broad band parallel to the winter ice lines close to the FYI tie point. The distance between the open-water tie point and the winter ice lines increases upward along these lines. We therefore observe a wide range of Bootstrap_p sea-ice concentrations between 70 and $\sim 100 \%$ at MODIS ice-surface fractions of $\sim 70 \%$ (compare Fig. 5e).

\subsection{Summer sea-ice tie points for the bootstrap algorithm}

We used open-water and sea-ice tie points representative of winter conditions (Sect. 2.3). We are not aware of summer sea-ice tie points for the ASI or Near90_lin and the NASA Team algorithms, but they do exist for the bootstrap algorithm. The solid cyan line in Fig. 6c denotes the summer seaice tie point for the Bootstrap_f algorithm taken from Comiso et al. (1997). For the Bootstrap_p algorithm (Fig. 6d), the solid and dashed cyan lines denote the summer sea-ice tie points for the periods 1-18 July and 19 July-4 August, respectively. For the period after 4 August, the summer ice line coincides with the winter ice line (black line in Fig. 6d).

We use MODIS ice-surface fractions of the period 20 June to 5 July to derive summer tie points from our summer brightness temperatures. We only select data of MODIS ice-surface fractions $>97.8 \%$ and of vertically polarized $37 \mathrm{GHz}$ brightness temperatures $>250 \mathrm{~K}$. We do not discriminate between different ice types. We compute summer sea-ice tie points (Table 11) at 19, 37, and $89 \mathrm{GHz}$ and from these also derive values of the normalized brightness-temperature polarization difference (PR). These summer sea-ice tie points are added to Fig. $6 \mathrm{c}$ and $\mathrm{d}$ as cyan crosses.

The potential impact of using summer instead of winter sea-ice tie points will be discussed in the following subsection.

\subsection{Temporal evolution}

During the melting season, changes in the snow and seaice microphysical properties, the associated variations in AMSR-E brightness temperatures, and the retrieved AMSRE sea-ice concentrations can occur within a few days. It is likely that Figs. 4-6 do blur such temporal variations, which, we think, need to be discussed to understand the observed differences in the sensitivity of the AMSR-E sea-ice concentration algorithms to the melt-pond fraction. Therefore we subdivide the MODIS and AMSR-E data sets used into pentads and discuss the temporal evolution for the four algorithms shown in Fig. 6.

\subsubsection{NASA Team algorithm}

For the NASA Team algorithm, in the first pentad (1-5 June, Fig. 7a), most summer data points are located at PR19 = $\sim 0.03$ (compare Table 11), and there is a GR3719 value between -0.05 and -0.01 . MODIS ice-surface fractions are $\sim 100 \%$. About $20 \%$ of the data points belong to the MYI class, while only seven data points belong to the FYI class (see Sect. 2.4). NASA Team sea-ice concentration and MODIS ice-surface fraction agree well with each other by means of slope and correlation coefficient. Later, summer data points cover a larger PR19 range, 0.02 to 0.08 , and a larger GR3719 range, 0.0 to -0.09 (16-20 June, Fig. 7b) 

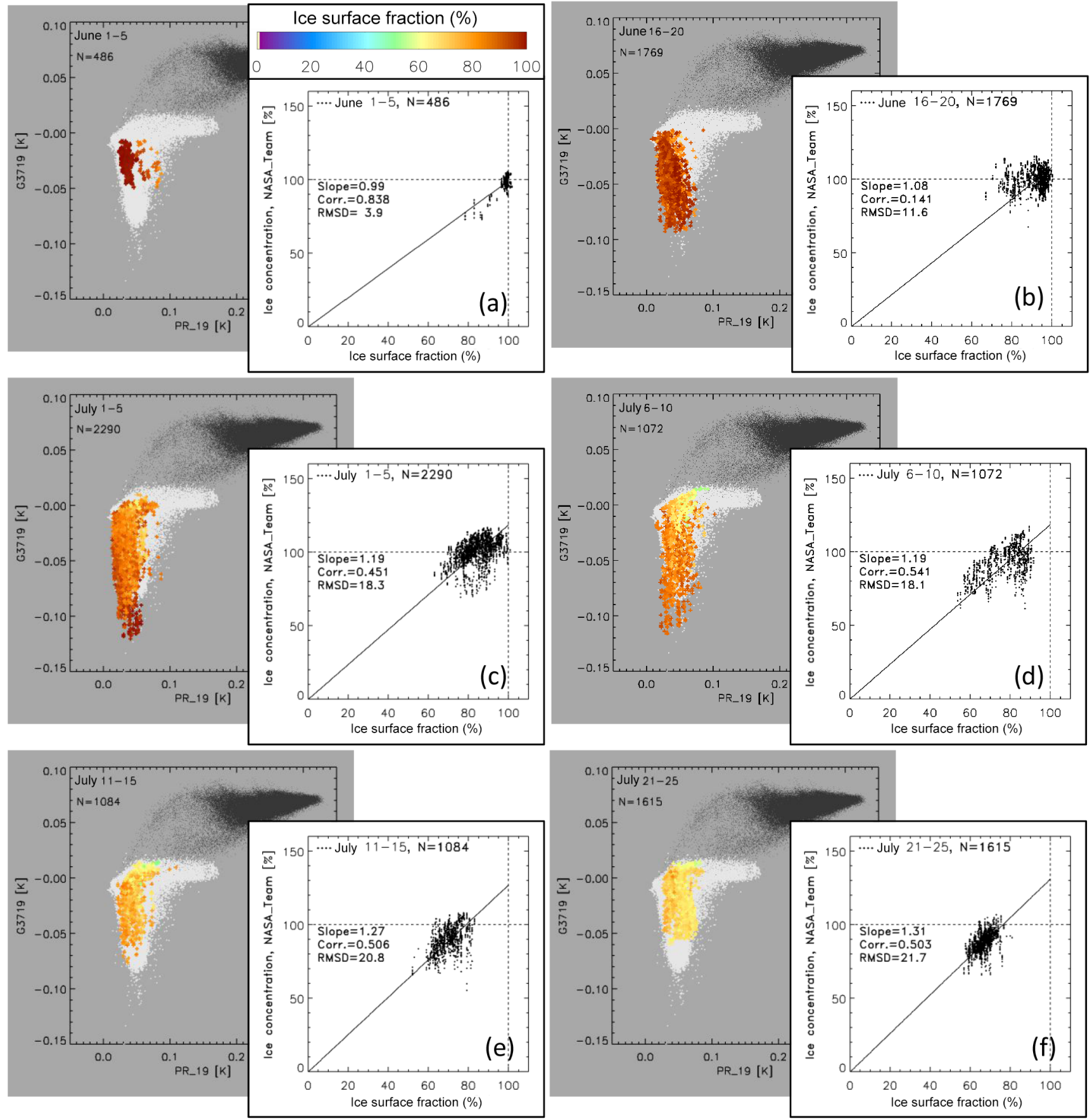

Figure 7. Background: AMSR-E brightness-temperature frequency difference (gradient ratio, GR) at 37 and $19 \mathrm{GHz}$, vertical polarization, vs. AMSR-E brightness-temperature polarization difference (polarization ratio, PR) at $19 \mathrm{GHz}$, color-coded with the co-located MODIS icesurface fraction for six selected pentads denoted in the upper left corner of each image together with the number $N$ of data pairs. For white and black dots, see Fig. 6. Foreground: NASA Team sea-ice concentration vs. MODIS ice-surface fraction for the same pentads together with the linear regression line forced through $(0,0)$. The slope of this line is given, together with the correlation between the two data sets and the root mean square difference (RMSD) of the two data sets in each image.

and 0.0 to $-0.12(1-5,6-10$ July, Fig. 7c, d). We explain the larger PR19 range by an increase in snow density (Table 2) and snow wetness (Table 1). We explain the expansion of
GR3719 towards more negative values by an increase in the surface layer snow grain size (Table 3 ). Figure $7 \mathrm{c}$ and $\mathrm{d}$ coincide with the onset of widespread melt-pond formation (see 
Fig. 3, days 30-40). MODIS ice-surface fractions are still mostly $>85 \%$ in Fig. 7 b, range between $\sim 100$ and $\sim 70 \%$ in Fig. $7 \mathrm{c}$ and decrease to between $\sim 90$ and $60 \%$ in Fig. $7 \mathrm{~d}$. With further melt progress, the PR19-GR3719 cloud shrinks to GR3719 values between +0.01 and -0.06 on $21-25$ July (Fig. 6f). At this stage MODIS ice-surface fractions are between 60 and $80 \%$.

NASA Team sea-ice concentrations exceed $100 \%$ on $16-$ 20 June and especially 1-5 July (Fig. 7b, c) with values up to $120 \%$. We find only few values $>100 \%$ for $21-25$ July, shortly after peak melt (Fig. 7f). After the good agreement between NASA Team sea-ice concentration and MODIS icesurface fraction for 1-5 June (Fig. 7a), it breaks down. During July the correlation between NASA Team sea-ice concentration and MODIS ice-surface fraction increases again, together with the slope, which reaches 1.31 for pentad 2125 July (Fig. 7f, compare Table 9). Correlations are $\sim 0.5$ for most of July which corresponds to an explained variance of about $25 \%$. Therefore, after the onset of widespread meltpond formation in the beginning of July 2009, NASA Team sea-ice concentrations and MODIS ice-surface fractions are linearly related to some degree; i.e., the NASA Team algorithm is sensitive to melt ponds. The relatively low correlation highlights the importance of other processes such as changes in those snow and sea-ice properties, which influence GR3719. These can be snow grain size and wetness (Tables 1, 3) and, after snowmelt, sea-ice salinity, roughness, and density (Eppler et al., 1992; Hallikainen and Winebrenner, 1992).

\subsubsection{Bootstrap_f algorithm}

For the Bootstrap_f algorithm, in the first pentad (1-5 June, Fig. 8a), most summer data points are associated with MODIS ice-surface fractions $\sim 100 \%$, and are located beyond the upper border of the winter data points and above the winter ice line (see Fig. 6c). Most Bootstrap_f sea-ice concentrations exceed $100 \%$ and overestimate the MODIS icesurface fraction. We can attribute these elevated brightness temperatures to elevated snow wetness (and density), which causes a larger increase in the vertically polarized brightness temperatures at $37 \mathrm{GHz}$ than at $19 \mathrm{GHz}$ (Table 1). On 16-20 June (Fig. 8b), almost all summer data points are located above the winter ice line and almost all Bootstrap_f sea-ice concentrations are $>100 \%$; maxima exceed $140 \%$. A cluster of MODIS ice-surface fractions can be identified at $\sim 95 \%$, which coincides with a cluster of Bootstrap_f sea-ice concentrations centered at $130 \%$. Until 1-5 July (Fig. 8c), the summer data points' cloud gradually expands towards lower values. Associated MODIS ice-surface fractions are lowest $(\sim 70 \%)$ along the bottom of the cloud and highest $(\sim 95 \%)$ at its left end. We attribute the latter to meltrefreeze cycles causing an increase in snow grain size associated with a smaller brightness-temperature decrease at $19 \mathrm{GHz}$ than at $37 \mathrm{GHz}$ (Table 3). These grid cells at the left end of the cloud are responsible for the Bootstrap_f seaice concentrations of $\sim 140 \%$ (compare Figs. $8 \mathrm{c}$ and $6 \mathrm{c}$ ). Throughout the remaining three pentads (Fig. 8d, e, f), summer data points shift towards lower $19 \mathrm{GHz}$ brightness temperatures and cover a smaller brightness-temperature range at both frequencies. We attribute this to complete snowmelt. Snow wetness and grain size variations do not influence the brightness temperatures anymore. MODIS ice-surface fractions are between 60 and $80 \%$ now (Fig. 8f); compare Fig. 7f. Maximum Bootstrap_f sea-ice concentrations decreased to $\sim 120 \%$ until 21-25 July.

The good agreement between Bootstrap_f sea-ice concentration and MODIS ice-surface fraction in the first pentad of June breaks down during June and re-emerges during July. Between the third pentad of July and the second pentad of August, average correlations are $\sim 0.65$ explaining $>40 \%$ of the variance. The average slope is 1.45 for these six pentads. Therefore, with the onset of widespread melt-pond formation Bootstrap_f sea-ice concentrations and MODIS ice-surface fractions are linearly related to each other; i.e., the Bootstrap_f algorithm is sensitive to melt ponds. This sensitivity is stronger than for the NASA Team algorithm (Sect. 4.3.1), which could be explained by a smaller influence of the other surface properties mentioned in the previous section.

It is difficult to quantify how this result would change by using summer sea-ice tie points, which we did not use to compute AMSR-E sea-ice concentrations with the two bootstrap algorithms for the reasons given in Sect. 2.3, but did include in Fig. 6c, d as cyan lines. The distance between the cyan line and the winter ice lines in proximity to the FYI tie point, measured along the dashed white line (Fig. 6c), suggests that we would reduce Bootstrap_f seaice concentrations by $10-15 \%$. Therefore, on the FYI side of the parameter space, Bootstrap_f sea-ice concentrations would be $\sim 100 \%$. However, to the left of the FYI tie point, the location of the summer data points (Figs. 6c, 8c, d) suggests that Bootstrap_f sea-ice concentrations would still be $>120 \%$. Therefore, using summer sea-ice tie points would reduce the slope between Bootstrap_f sea-ice concentrations and MODIS ice-surface fractions, but whether the correlations would be similarly high and whether we can exclude unknown nonlinear effects cannot be answered in the present paper.

\subsubsection{The other algorithms}

The temporal evolution of Bootstrap_p sea-ice concentrations in relation to the MODIS ice-surface fraction during June is similar to the Bootstrap_f algorithm (Fig. S1a, b in the Supplement). One principal difference is the smaller slope we obtain with Bootstrap_p sea-ice concentrations compared to the Bootstrap_f algorithm: $\sim 0.9$ vs. $\sim 1.1$ for $1-5$ June and $\sim 1.1$ vs. 1.3 for $1-5$ July; additionally, correlations are smaller. Secondly, we find larger variations of Bootstrap_p sea-ice concentrations around MODIS ice-surface fractions; 

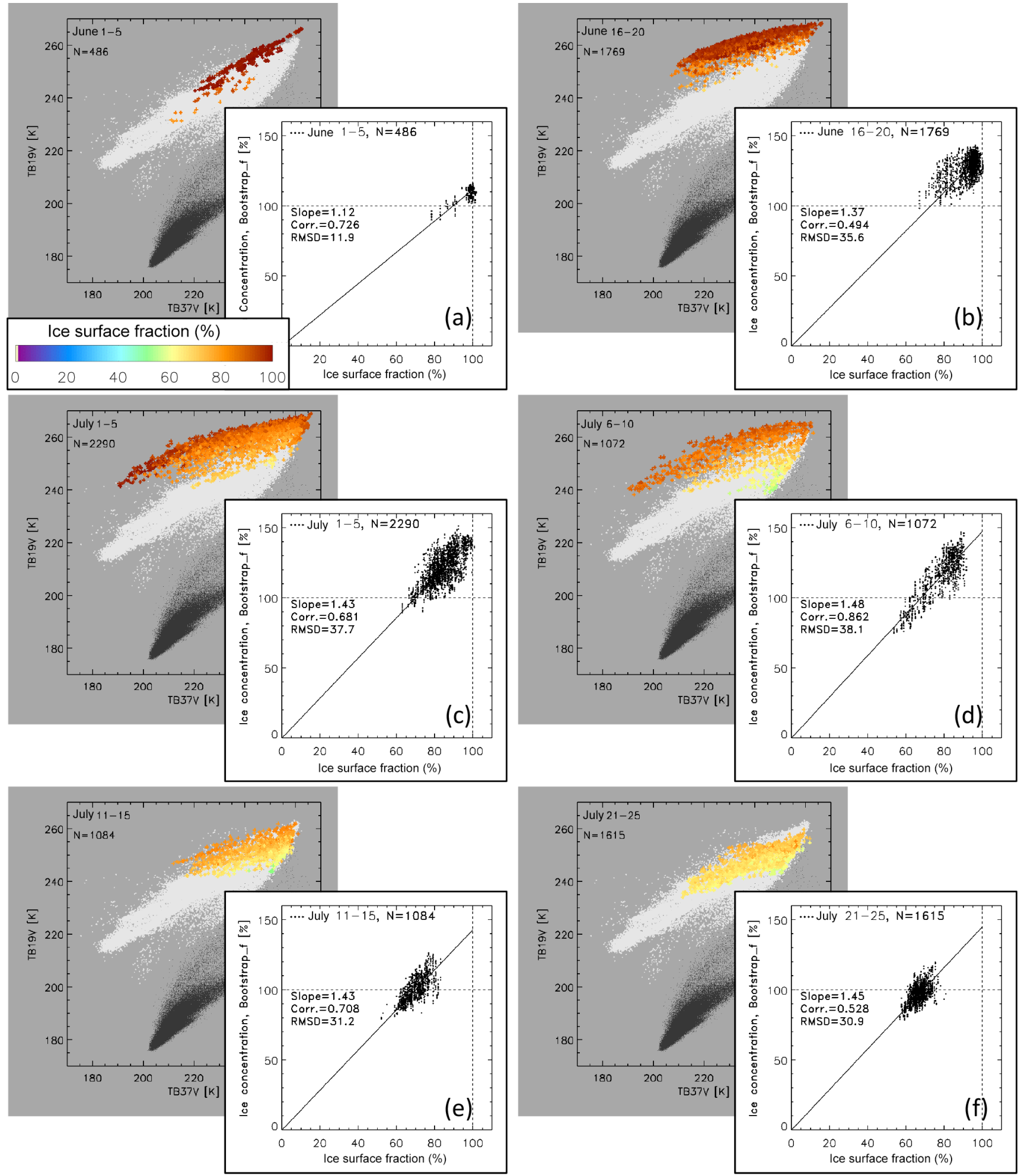

Figure 8. Background: vertically polarized AMSR-E brightness temperature at $19 \mathrm{GHz}$ vs. at $37 \mathrm{GHz}$, color-coded with the co-located MODIS ice-surface fraction for the same six selected pentads as in Fig. 7 denoted in the upper left corner of each image, together with the number $N$ of data pairs. For white and black dots, see Fig. 6. Foreground: same as in Fig. 7 but for the Bootstrap_f algorithm. 
for example, Bootstrap_p sea-ice concentrations range from 50 to $110 \%$ at $90 \%$ MODIS ice-surface fraction. We attribute this to the large and polarization-dependent sensitivity of $37 \mathrm{GHz}$ brightness temperatures to variations in snow properties (Tables 1, 2, 3). In June, any linear relationship to the emerging melt-pond coverage is obscured by this sensitivity. During the first two July pentads, scatter is as high as during most of June. Brightness temperatures associated with MODIS ice-surface fractions of $\sim 90$ and $\sim 60 \%$ are often located right next to each other in the algorithms' parameter space (Fig. S1c, d), which is different to the Bootstrap_f algorithm (Fig. 8c, d). After mid-July, a linear relationship between Bootstrap_p sea-ice concentration and MODIS icesurface fraction emerges. The average slope is 1.25 and correlations increase from 0.34 (16-20 July) to 0.76 (6-10 August). In summary, the Bootstrap_p algorithm is also sensitive to melt ponds. The sensitivity is smaller than for the Bootstrap_f algorithm, and snow-property variations seem to be of larger influence.

How does this result change if we use summer sea-ice tie points (Fig. 6d, cyan lines, and Sect. 4.3.2)? The early summer ice line (Fig. 6d, solid cyan line) is steeper than the winter ice lines, and intersects them close to the FYI tie point. Therefore, close to the FYI tie point and to the right, all summer data points are below the summer ice line, causing Bootstrap_p sea-ice concentrations $<100 \%$. However, to the left of the FYI tie point, summer data points are located above the summer ice line, causing Bootstrap_p sea-ice concentrations of up to $\sim 130 \%$ close to the MYI tie point (Fig. 6d). Therefore, for data from 2009, using the early summer sea-ice tie points would not generally provide sea-ice concentrations, which improve the relationship between Bootstrap_p sea-ice concentrations and MODIS ice-surface fractions. The midsummer ice line (Fig. 6d, dashed cyan line) is located parallel below the winter ice lines. A large fraction of the summer data points is located above the summer ice line, causing Bootstrap_p sea-ice concentrations $>100 \%$. For instance, for 21-25 July (Fig. S1f), about one-third of the data points would have a Bootstrap_p sea-ice concentration $>100 \%$; this is currently three data points. Therefore, for data from 2009, using the midsummer sea-ice tie points would increase Bootstrap_p sea-ice concentrations and increase the slope between them and MODIS ice-surface fractions, but would not necessarily improve the correlation. Compared to the winter sea-ice tie points, using the early summer (midsummer) sea-ice tie points would result in a decreased (enhanced) sensitivity of the Bootstrap_p algorithm to melt ponds.

The temporal development of brightness temperatures, sea-ice concentrations, and ice-surface fractions obtained with the Near90_lin algorithm (Figs. S2, 6b) is comparable to that obtained with the Bootstrap_p algorithm (Fig. S1). The scatter in summer data points and the scatter between Near90_lin sea-ice concentrations and MODIS ice-surface fractions is a little less pronounced and peaks earlier. We attribute the scatter again to snow-property variations (Ta- bles 1, 2, 3). For the smaller electromagnetic wavelength at $89 \mathrm{GHz}$ compared to $37 \mathrm{GHz}$, scattering by coarse-grained snow is more effective than the impact of snow wetness, which is evident in the migration of summer data points towards lower values (compare Figs. S1b and S2b). Maximum Near90_lin sea-ice concentrations of 120\% (Fig. S2b) are larger than we expect from comparison with Fig. $6 \mathrm{~b}$ and can possibly be attributed to an unaccounted weather influence in the open-water tie point (Fig. 6b, white line). After mid-July, correlations increase to their maximum in 610 August of 0.81 . Slopes are considerably larger than for the Bootstrap_p sea-ice concentration and vary around 1.33. Slopes and correlations vary considerably between pentads, which we attribute mainly to the larger weather influence at $89 \mathrm{GHz}$. Enhanced sensitivity of the smaller electromagnetic wavelength at $89 \mathrm{GHz}$ to surface property variations, be it remaining or new snow (Grenfell, 1986) or sea-ice surface wetness changes, might also contribute. We conclude that the Near90_lin algorithm, or other algorithms employing near$90 \mathrm{GHz}$ data such as the ASI algorithm, is only sensitive to melt ponds to some degree. Snow and sea-ice property variations, but also the weather influence, impact sea-ice concentration retrieval with this type of algorithm as much as or even more than we observe for the Bootstrap_p algorithm.

With respect to the $6 \mathrm{H}$ algorithm and the Bristol algorithm, we state that both algorithms reveal a temporal development of slopes and correlations between AMSR-E sea-ice concentrations and MODIS ice-surface fractions (Figs. S3, S4, Tables $8,9,10)$, which are similar to the Bootstrap_f algorithm. Both algorithms, $6 \mathrm{H}$ more than Bristol, are sensitive to melt ponds.

\subsubsection{Implications for summer sea-ice concentrations}

A MODIS ice-surface fraction value of $60 \%$ can, in reality, be anything between case A, $100 \%$ sea ice with $40 \%$ meltpond fraction, and case B, $60 \%$ sea ice with $0 \%$ melt-pond fraction, as laid out in the Introduction. Slopes between the AMSR-E sea-ice concentration and the MODIS ice-surface fraction obtained, for example, for the NASA Team algorithm, of 1.31 (Fig. 7f) would convert 60\% MODIS icesurface fraction into $78 \%$ NASA Team sea-ice concentration. In case B this would be an overestimation by $18 \%$, while in case A this would be an underestimation by $22 \%$.

We compute the average slope and correlation values of all algorithms, except ASI and NT2, for the six pentads 1115 July to 6-10 August together with a resulting over- or underestimation of the actual sea-ice concentrations of cases $\mathrm{A}$ and $\mathrm{B}$ for which we chose ice-surface fractions of 60 and $80 \%$. The Bootstrap_f algorithm is most sensitive to melt ponds (highest slope), followed by the Bristol and $6 \mathrm{H}$ algorithms (Table 12). The Bootstrap_p algorithm is least sensitive to melt ponds (lowest slope), followed by the NASA Team algorithm. This sensitivity is most pronounced for the Bristol algorithm (largest correlation), followed by the Boot- 
Table 12. Slope of the linear relationship and correlation between AMSR-E sea-ice concentrations and MODIS ice-surface fractions for the six algorithms, which do not cut off sea-ice concentrations, averaged over the six pentads from 11-15 July to 6-10 August. For each algorithm, the average value \pm 1 standard deviation (SD), the range in the slope values, and the range in the correlations are given. (EV) denotes the explained variance. Cases A60 and A80 denote $100 \%$ sea-ice concentration with 40 and $20 \%$ (apparent) open-water fraction due to melt ponds, i.e., 60 and $80 \%$ ice-surface fraction, respectively. Case B60 and B80 denote 60 and $80 \%$ sea-ice concentration in the case of 40 and $20 \%$ real open-water fraction; i.e., the ice-surface fraction $=$ the sea-ice concentration. A " ** " indicates saturation; i.e., the retrieved AMSR-E sea-ice concentration exceeds $100 \%$. Bold numbers denote the maximum values for mean slope and mean correlation.

\begin{tabular}{|c|c|c|c|c|c|c|}
\hline Algorithm & $6 \mathrm{H}$ & Bootstrap_f & Bootstrap_p & Bristol & NASA Team & Near90_lin \\
\hline Mean slope \pm 1 SD & $1.36 \pm 0.04$ & $1.44 \pm 0.02$ & $1.24 \pm 0.03$ & $1.36 \pm 0.02$ & $1.29 \pm 0.03$ & $1.33 \pm 0.03$ \\
\hline $\begin{array}{l}\text { Mean correlation } \pm 1 \mathrm{SD} \\
(\mathrm{EV})\end{array}$ & $\begin{array}{c}0.55 \pm 0.16 \\
(30 \%)\end{array}$ & $\begin{array}{c}0.62 \pm 0.10 \\
(38 \%)\end{array}$ & $\begin{array}{l}0.49 \pm 0.14 \\
(24 \%)\end{array}$ & $\begin{array}{c}0.68 \pm 0.09 \\
(46 \%)\end{array}$ & $\begin{array}{l}0.51 \pm 0.10 \\
(26 \%)\end{array}$ & $\begin{array}{c}0.46 \pm 0.20 \\
(21 \%)\end{array}$ \\
\hline Slope range & 1.29 to 1.41 & 1.41 to 1.47 & 1.21 to 1.29 & 1.34 to 1.39 & 1.26 to 1.32 & 1.29 to 1.38 \\
\hline \multirow[t]{2}{*}{ Correlation } & 0.33 to 0.78 & 0.48 to 0.79 & 0.34 to 0.76 & 0.58 to 0.82 & 0.38 to 0.69 & 0.21 to 0.81 \\
\hline & \multicolumn{6}{|c|}{ Underestimation of case A/overestimation of case $\mathrm{B}$ sea-ice concentrations by the respective algorithm } \\
\hline Case A60 & $-18.4 \%$ & $-13.6 \%$ & $-25.6 \%$ & $-18.4 \%$ & $-22.6 \%$ & $-20.2 \%$ \\
\hline Case A80 & $0.0 \% *$ & $0.0 \% *$ & $-0.8 \%$ & $0.0 \% *$ & $0.0 \% *$ & $0.0 \% *$ \\
\hline Case B60 & $+21.6 \%$ & $+26.4 \%$ & $+14.4 \%$ & $+21.6 \%$ & $+17.4 \%$ & $+19.8 \%$ \\
\hline Case B80 & $+20.0 \% *$ & $+20.0 \% *$ & $+19.2 \%$ & $+20.0 \% *$ & $+20.0 \% *$ & $+20.0 \% *$ \\
\hline
\end{tabular}

strap_f algorithm. The sensitivity is least pronounced for the Near90_lin algorithm (smallest correlation), followed by the Bootstrap_p algorithm. Most pronounced means that snow and sea-ice property variations as well as the weather influence have a comparably small influence. These variations have a larger influence on AMSR-E sea-ice concentrations retrieved with an algorithm with a less pronounced sensitivity to melt ponds. The algorithms with the largest sensitivity to melt ponds interestingly provide the smallest underestimation of the concentration of melt-pond-covered sea ice and the largest overestimation of the concentration of non-ponded sea ice (e.g., the Bootstrap_f and Bristol algorithms, Table 12). The algorithms with the smallest sensitivity to melt ponds provide the largest underestimation of the concentration of melt-pond-covered sea ice and the smallest overestimation of the concentration of non-ponded sea ice (e.g., Bootstrap_p, Table 12).

Using summer sea-ice tie points for the Bootstrap_f algorithm would presumably reduce the mean slope as discussed in Sect. 4.3.2, leading to a smaller under- and overestimation of the sea-ice concentrations of cases A and B, compared to Table 12. Using the midsummer tie point for the Bootstrap_p algorithm would, in contrast, presumably increase the mean slope as discussed in Sect. 4.3.3, leading to a larger underand overestimation of the sea-ice concentrations of cases A and $\mathrm{B}$, respectively, compared to Table 12 .

\section{Conclusions}

We investigate the sensitivity to melt ponds of eight seaice concentration retrieval algorithms based on satellite microwave brightness temperatures, by comparing contemporary daily estimates of sea-ice concentration and melt-pond fraction. We derive gridded daily sea-ice concentrations from the Advanced Microwave Scanning Radiometer aboard the Earth Observation Satellite (AMSR-E) brightness temperatures of June-August 2009. We use a consistent set of tie points to aid intercomparison of the algorithms. We derive the gridded daily fraction of melt ponds, open water between ice floes, and ice-surface fraction from contemporary Moderate Resolution Spectroradiometer (MODIS) reflectance measurements with a neural network based classification approach. We discuss potential uncertainty sources of these data, and conclude that MODIS ice-surface fractions are as accurate as $5-10 \%$. We carry out the comparison of AMSR$\mathrm{E}$ and MODIS data sets at $100 \mathrm{~km}$ grid resolution.

AMSR-E sea-ice concentrations agree fairly well with MODIS sea-ice concentrations, the sum of the ice-surface fraction, and the melt-pond fraction, with slopes of a linear regression between 0.90 and 1.16. However, for some algorithms, AMSR-E sea-ice concentrations scatter widely for MODIS sea-ice concentrations larger than $80 \%$. We note that the eventual overestimation of the concentration of the sea ice in between the melt ponds, to produce seemingly "correct" sea-ice concentrations that include the melt ponds, will result in incorrectly overestimating the concentration of sea ice in areas with real open water.

We isolate the influence of melt ponds by only comparing AMSR-E sea-ice concentrations with MODIS ice-surface fractions for grid cells with MODIS sea-ice concentrations 
above $90 \%$. By doing so, we can use the ice-surface fraction instead of the melt-pond fraction as a measure of the impact of melt ponds and can keep the effect of potential misclassification between the two spectrally close surface types, open water and melt ponds, as small as possible. For most of June, we find a nonlinear relation between both data sets. We attribute this to the influence of snow-property variations impacting the microwave brightness temperatures and a meltpond fraction that is still small. After June, for one group of algorithms, e.g., the Bristol and Comiso Bootstrap frequency mode (Bootstrap_f) algorithms, sea-ice concentrations are linearly related to MODIS ice-surface fractions. For other algorithms, e.g., Near90GHz and Comiso Bootstrap polarization mode (Bootstrap_p), the linear relationship is weaker and develops later in summer.

We take the degree of correlation between AMSR-E seaice concentration and MODIS ice-surface fraction as a measure of an algorithm's sensitivity to the melt ponds, and use the obtained linear regression slope to estimate differences between actual and retrieved sea-ice concentration. All algorithms underestimate the sea-ice concentration of $100 \%$ sea ice with an open-water fraction of $40 \%$ due to melt ponds (case A) by between $14 \%$ (Bootstrap_f) and 26\% (Bootstrap_p). The underestimation reduces to $0 \%$ for a melt-pond fraction of $\sim 20 \%$. The concentration of sea ice with a similarly large open-water fraction due to leads and openings between the ice floes (case B) is overestimated by between $26 \%$ (Bootstrap_f) and 14\% (Bootstrap_p) for $60 \%$ sea-ice concentration and by $20 \%$ for all algorithms for $80 \%$ sea-ice concentration.

One next step would be to extend the analysis to more years to confirm the results of our case study with a larger number of data. Currently, at pentad scale, the number of data is too small to use a higher MODIS sea-ice concentration threshold of, e.g., $98 \%$ to better isolate the influence of melt ponds. Based on a substantially smaller number of data, using a threshold of $98 \%$ at monthly instead of a pentad scale, we find that for the month of July, the correlation between AMSR-E sea-ice concentrations and MODIS icesurface fraction increases from 0.86 to 0.92 (Bootstrap_f), from 0.85 to 0.91 (Bristol), and from 0.67 to 0.76 (NASA Team), while the slopes of the linear regression remain similar.

For reasons outlined in the description of the algorithms, we use a consistent set of sea-ice tie points derived for winter conditions. By applying published summer sea-ice tie points for the bootstrap algorithms, we find that the slopes of the linear regression would be reduced for Bootstrap_f but not for Bootstrap_p. As a result, Bootstrap_f would underestimate sea-ice concentrations for case A less, but overestimate sea-ice concentrations for case B more.

We suggest that algorithms that are more sensitive to melt ponds could be easily optimized further because the influence of snow and sea-ice surface property variations, of which distribution is unknown, seems to be less pronounced, while methods to derive melt-pond fraction, which would be needed for the optimization, have been developed. According to our results, this applies to the Bootstrap_f, Bristol, and Near90_lin algorithms, and the CalVal algorithm, which is similar to the Bootstrap_f mode and is used in the SICCI algorithm. The Bootstrap_p and NASA Team algorithms seem to be less suitable for further optimization. While these seem to have the lowest sensitivity to melt ponds, and therefore lowest underestimation for case A, they seem to overestimate the sea-ice concentration for case B most among the algorithms investigated.

\section{Data availability}

The following data are used in the present paper:

- AMSR-E/Aqua L2A global swath spatially resampled brightness temperatures data set, version 3 : http://nsidc.org/data/docs/daac/ae_12a_tbs.gd.html, doi:10.5067/AMSR-E/AE_L2A.003;

- MODIS surface reflectance daily L2G global $500 \mathrm{~m}$ and $1 \mathrm{~km}$ product (MOD09GA: http: //reverb.echo.nasa.gov/reverb/) on sinusoidal tile grid used for MODIS L2 data: http://landweb.nascom. nasa.gov/developers/sn_tiles/sn_grid.html;

- NT2 sea ice concentration from the AMSR-E/AQUA daily L3 $12.5 \mathrm{~km}$ brightness temperature, sea ice concentration and snow depth polar grids product, version 3 (http://nsidc.org/data/docs/daac/ae_si12_12km_ tb_sea_ice_and_snow.gd.html), doi:10.5067/AMSRE/AE_SI12.003;

- EASE Grid sea ice age, NSIDC, DAAC, doi:10.5067/PFSVFZA9Y85G.

The daily MODIS melt pond fraction data set co-located with AMSR-E brightness temperatures and sea ice concentrations is owned by the ESA SICCI project and is available upon request by sending an email to stefan.kern@unihamburg.de or icdc.cen@lists.uni-hamburg.de.

\section{The Supplement related to this article is available online at doi:10.5194/tc-10-2217-2016-supplement.}

Acknowledgements. The work leading to this paper was funded by ESA/ESRIN via the Climate Change Initiative under the SICCI project for all authors but Stefan Kern. Stefan Kern acknowledges support from the Center of Excellence for Climate System Analysis and Prediction (CliSAP), University of Hamburg, Germany. We thank the named and the anonymous reviewers for very constructive and helpful comments which helped to substantially improve the manuscript.

Edited by: E. Hanna

Reviewed by: G. Flato, G. Heygster, and one anonymous referee 


\section{References}

Andersen, S., Tonboe, R. T., Kaleschke, L., Heygster, G., and Pedersen, L. T.: Intercomparison of passive microwave sea ice concentration retrievals over the high-concentration Arctic sea ice, J. Geophys. Res., 112, C08004, doi:10.1029/2006JC003543, 2007.

Ashcroft, P. and Wentz, F. J.: AMSR-E/Aqua L2A global swath spatially-resampled brightness temperatures data set, version 3, [2009-06-01 to 2009-08-31], NASA DAAC at the National Snow and Ice Data Center, Boulder, Colorado, USA, doi:10.5067/AMSR-E/AE_L2A.003, 2013.

Baum, B. A., Menzel, W. P., Frey, R. A., Tobin, D. C., Holz, R. E., and Ackerman, S. A.: MODIS cloud-top property refinement for Collection 6, J. Appl. Meteorol. Clim., 51, 1145-1163, doi:10.1175/JAMC-D-11-0203.1, 2012.

Beitsch, A.: Uncertainties of a near $90 \mathrm{GHz}$ sea ice concentration retrieval algorithm. Dissertationsschrift, Universität Hamburg, available at: http://ediss.sub.uni-hamburg.de/volltexte/ 2014/7070/pdf/Dissertation.pdf, last access: 2 June 2016, 2014.

Cavalieri, D. J., Gloersen, P., and Campbell, W. J.: Determination of sea ice parameters with the NIMBUS 7 SMMR, J. Geophys. Res., 89, 5355-5369, 1984.

Cavalieri, D. J., Burns, B. A., and Onstott, R. G.: Investigation of the effects of summer let on the calculation of sea ice concentration using active and passive microwave data, J. Geophys. Res., 95, 5359-5369, 1990.

Cavalieri, D. J., Markus, T., and Comiso, J. C.: AMSR-E/AQUA daily L3 $12.5 \mathrm{~km}$ brightness temperature, sea ice concentration and snow depth polar grids product, version 3, [JuneAugust 2009], NASA National Snow and Ice Data Center Distributed Active Archive Center, Boulder, Colorado USA, doi:10.5067/AMSR-E/AE_SI12.003, 2014.

Chan, M. A. and Comiso, J. C.: Arctic cloud characteristics as derived from MODIS, CALIPSO, and CloudSat, J. Climate, 26, 3285-3306, doi:10.1175/JCLI-D-12-00204.1, 2013.

Comiso, J. C.: Characteristics of arctic winter sea ice from satellite multispectral microwave observations, J. Geophys. Res., 91, 975-994, 1986.

Comiso, J. C.: Enhanced sea ice concentrations and ice extents from AMSR-E data, Journal of The Remote Sensing Society of Japan, 29, 199-215, 2009.

Comiso, J. C.: Large decadal decline of the Arctic multiyear ice cover, J. Climate, 25, 1176-1193, doi:10.1175/JCLI-D-1100113.1, 2012.

Comiso, J. C. and Kwok, R.: Surface and radiative characteristics of the summer Arctic sea ice cover from multisensory satellite observation, J. Geophys. Res., 101, 28397-28416, 1996.

Comiso, J. C., Cavalieri, D. J., Parkinson, C. L., and Gloersen, P.: Passive microwave algorithms for sea ice concentration: A comparison of two techniques, Remote Sens. Environ., 60, 357-384, 1997.

Divine, D. V., Granskog, M. A., Hudson, S. R., Pedersen, C. A., Karlsen, T. I., Divina, S. A., Renner, A. H. H., and Gerland, S.: Regional melt-pond fraction and albedo of thin Arctic firstyear drift ice in late summer, The Cryosphere, 9, 255-268, doi:10.5194/tc-9-255-2015, 2015.

Eastwood, S. (Ed.): Ocean \& Sea Ice SAF (OSISAF) Sea Ice Product Manual, Version 3.8, available at: http://osisaf.met.no, last access: February 2015, May 2012
Eicken, H., Grenfell, T. C., Perovich, D. K., Richter-Menge, J. A., and Frey, K.: Hydraulic controls of summer Arctic pack ice albedo, J. Geophys. Res., 109, C08007, doi:10.1029/2003JC001989, 2004.

Eppler, D. T., Farmer, L. D., Lohanick, A. W., Anderson, M. R., Cavalieri, D. J., Comiso, J. C., Gloersen, P., Garrity, C., Grenfell, T. C., Hallikainen, M., Maslanik, J. A., Mätzler, C., Melloh, R. A., Rubinstein, I., and Swift, C. T.: Passive microwave signatures of sea ice, in: Microwave Remote Sensing of Sea Ice, edited by: Carsey, F., AGU Monograph 68, 47-71, 1992.

Fetterer, F. and Untersteiner, N.: Observations of melt ponds on Arctic sea ice, J. Geophys. Res., 103, 24821-24835, 1998.

Flocco, D., Feltham, D. L., and Turner, A. K.: Incorporation of a physically based melt pond scheme into the sea ice component of a climate model, J. Geophys. Res., 115, C08012, doi:10.1029/2009JC005568, 2010.

Fowler, C., Emery, W., and Maslanik, J. A.: Satellite derived arctic sea ice evolution Oct. 1978 to March 2003, IEEE Geosci. Remote S., 1, 71-74, 2003.

Fuhrhop, R., Grenfell, T. C., Heygster, G., Johnsen, K.-P., Schlüssel, P., Schrader, M., and Simmer, C.: A combined radiative transfer model for sea ice, open ocean, and atmosphere, Radio Sci., 33, 303-316, 1998.

Garrity, C.: Characterization of snow on floating ice and case studies of brightness temperature changes during the onset of melt, in: Microwave remote sensing of sea ice, edited by: Carsey, F., AGU Monograph, 68, 313-328, 1992.

Gogineni, S. P., Moore, R. K., Grenfell, T. C., Barber, D. G., Digby, S., and Drinkwater, M.: The effects of freeze-up and melt process on microwave signature, chapter 17, in: Microwave remote sensing of sea ice, edited by: Carsey, F., AGU Monograph, 68, 329-341, 1992.

Grenfell, T. C.: Surface-based passive microwave observations of sea ice in the Bering and Greenland Seas, IEEE T. Geosci. Remote, GE-24, 378-382, 1986.

Grenfell, T. C. and Lohanick, A. W.: Temporal variations of the microwave signature of sea ice during the late spring and early summer near Mould Bay, Northwest Territories, J. Geophys. Res., 90, 5063-5074, 1985.

Hallikainen, M. and Weinbrenner, D. P.: The physical basis for sea ice remote sensing, chapter 3, in: Microwave remote sensing of sea ice, edited by: Carsey, F., AGU Monograph 68, 47-71, 1992.

Holland, M. M., Bailey, D. A., Briegleb, B. P., Light, B., and Hunke, E.: Improved sea ice shortwave radiation physics in CCSM4: The impact of melt ponds and aerosols on Arctic sea ice, J. Climate, 25, 1413-1430, doi:10.1175/JCLI-D-11-00078.1, 2012.

Istomina, L., Heygster, G., Huntemann, M., Schwarz, P., Birnbaum, G., Scharien, R., Polashenski, C., Perovich, D., Zege, E., Malinka, A., Prikhach, A., and Katsev, I.: Melt pond fraction and spectral sea ice albedo retrieval from MERIS data Part 1: Validation against in situ, aerial, and ship cruise data, The Cryosphere, 9, 1551-1566, doi:10.5194/tc-9-1551-2015, $2015 \mathrm{a}$.

Istomina, L., Heygster, G., Huntemann, M., Marks, H., Melsheimer, C., Zege, E., Malinka, A., Prikhach, A., and Katsev, I.: Melt pond fraction and spectral sea ice albedo retrieval from MERIS data Part 2: Case studies and trends of sea ice albedo and melt ponds in the Arctic for years 2002-2011, The Cryosphere, 9, 15671578, doi:10.5194/tc-9-1567-2015, 2015 b. 
Ivanova, N., Pedersen, L. T., and Tonboe, R. T. Product Validation and Algorithm Selection Report (PVASR): Sea Ice Concentration, version 1.1, 28 August 2013, SICCI Project Report D2.5, Doc Ref: SICCI-PVASR (SIC), 2013.

Ivanova, N., Pedersen, L. T., Lavergne, T., Tonboe, R. T., Rinne, E., and Ridout, A.: Algorithm Theoretical Basis Document, version 1.0 (ATBDv2), May 13, SICCI Project Report D3.6, Doc Ref: SICCI-ATBDv2-13-09, 2014.

Ivanova, N., Pedersen, L. T., Tonboe, R. T., Kern, S., Heygster, G., Lavergne, T., Sørensen, A., Saldo, R., Dybkjær, G., Brucker, L., and Shokr, M.: Inter-comparison and evaluation of sea ice algorithms: towards further identification of challenges and optimal approach using passive microwave observations, The Cryosphere, 9, 1797-1817, doi:10.5194/tc-9-17972015, 2015.

Kaleschke L., Lüpkes, C., Vihma, T., Haarpaintner, J., Bochert, A., Hartmann, J., and Heygster, G.: SSM/I Sea Ice Remote Sensing for Mesoscale Ocean-Atmosphere Interaction Analysis, Can. J. Remote Sens., 27, 526-537, 2001.

Karlsson, K.-G. and Dybbroe, A.: Evaluation of Arctic cloud products from the EUMETSAT Climate Monitoring Satellite Application Facility based on CALIPSO-CALIOP observations, Atmos. Chem. Phys., 10, 1789-1807, doi:10.5194/acp-10-17892010, 2010.

Kern, S., Zygmuntowska, M., Khvorostovsky, K. Spreen, G., Ivanova, N., and Beitsch, A.: Product Validation and Intercomparison Report, PVIR, Version 1.1, 25 February 2015, SICCI Project Report D4.1, Doc Ref: SICCI-PVIR, 2015.

King, M. D., Platnick, S., Menzel, W. P., Ackerman, S. A., and Hubanks, P. A.: Spatial and temporal distribution of clouds observed by MODIS onboard the Terra and Aqua Satellites, IEEE T. Geosci. Remote, 51, 3826-3852, 2013.

Landy, J., Ehn, J., Shields, M., and Barber, D.: Surface and melt pond evolution on landfast first-year sea ice in the Canadian Arctic Archipelago, J. Geophys. Res.-Oceans, 119, 3054-3075, doi:10.1002/2013JC009617, 2014.

Mäkynen, M., Kern, S., Rösel, A., and Pedersen, L. T.: On the estimation of melt pond fraction on the Arctic sea ice with Envisat WSM images, IEEE T. Geosci. Remote, 52, 7366-7379, doi:10.1109/TGRS.2014.2311476, 2014.

Marks, H.: Investigation of algorithms to retrieve melt pond fraction on Arctic sea ice from optical satellite observations, Master Thesis, Institute of Astronomy \& Astrophysics Computational Physics, Eberhard Karls Universität Tübingen and Institute of Environmental Physics, Universität Bremen, 82 pp., June 2015.

Markus, T. and Cavalieri, D. J.: An enhancement of the NASA Team sea ice algorithm, IEEE T. Geosci. Remote, 38, 13871398, 2000.

Maykut, G. A. and Untersteiner, N.: Some results from a time dependent thermodynamic model of Arctic sea ice, J. Geophys. Res., 76, 1550-1575, 1971.

Meier, W.: Comparison of passive microwave ice concentration algorithm retrievals with AVHRR imagery in the Arctic peripheral seas, IEEE T. Geosci. Remote, 43, 1324-1337, doi:10.1109/TGRS.2005.846151, 2005.

MODLAND Developers: MODIS surface data, available at: http:// landweb.nascom.nasa.gov/developers/sn_tiles/sn_grid.html, last access: 16 September 2016.
Pedersen, L. T.: Merging microwave radiometer data and meteorological data for improved sea ice concentrations, EARSeL Advances in Remote Sensing, 3, No. 2-XII, 9 pp., 1994.

Perovich, D. K., Richter-Menge, J., Polashenski, C., Elder, B., Arbetter, T., and Brennick, G.: Sea ice mass balance observations from the North Pole Environmental Observatory, Geophys. Res. Lett., 41, 2019-2025, doi:10.1002/2014GL059356, 2014.

Perovich, D. K., Tucker III, W. B., and Ligett, K. A.: Aerial observations of the evolution of ice surface conditions during summer, J. Geophys. Res., 107, 8048, doi:10.1029/2000JC000449, 2002.

Perovich, D. K. and Polashenski, C.: Albedo evolution of seasonal Arctic sea ice, Geophys. Res. Lett., 39, L08501, doi:10.1029/2012GL051432, 2012.

Petrich, C., Eicken, E., Polashenski, C. M., Sturm, M., Harbeck, J. P., Perovich, D. K., and Finnegan, D. C.: Snow dunes: A controlling factor of melt pond distribution on Arctic sea ice, J. Geophys. Res., 117, C09029, doi:10.1029/2012JC008192, 2012.

Polashenski, C., Perovich, D. K., and Courville, Z.: The mechanisms of sea ice melt pond formation and evolution, J. Geophys. Res., 117, C01001, doi:10.1029/2011JC007231, 2012.

Rösel, A., Kaleschke, L., and Birnbaum, G.: Melt ponds on Arctic sea ice determined from MODIS satellite data using an artificial neural network, The Cryosphere, 6, 431-446, doi:10.5194/tc-6431-2012, 2012a.

Rösel, A., Kaleschke, L., and Kern, S.: Influence of melt ponds on microwave sensor's sea ice concentration retrieval algorithms, IGARSS 2012, 23-27 July 2012, Munich, Germany, 2012b.

Sankelo, P., Haapala, J., Heiler, I., and Rinne, E.: Melt pond formation and temporal evolution at the drifting station Tara during summer 2007, Polar Res., 29, 311-321, doi:10.1111/j.17518369.2010.00161.x, 2010.

Scharien, R. K., Geldsetzer, T., Barber, D. G., Yackel, J. J., and Langlois, A.: Physical, dielectric, and $\mathrm{C}$ band microwave scattering properties of first-year sea ice during advanced melt, J. Geophys. Res., 115, C12026, doi:10.1029/2010JC006257, 2010.

Smith, D. M.: Extraction of winter total sea-ice concentration in the Greenland and Barents Seas from SSM/I data, Int. J. Remote Sens., 17, 2625-2646, 1996.

Spreen, G., Kaleschke, L., and Heygster, G.: Sea ice remote sensing using AMSR-E 89-GHz channels, J. Geophys. Res., 113, C02S03, doi:10.1029/2005JC003384, 2008.

Steffen, K. and Schweiger, A.: NASA team algorithm for sea ice concentration retrieval from Defense Meteorological Satellite Program special sensor microwave imager: comparison with Landsat satellite data, J. Geophys. Res., 96, 21971-21987, 1991.

Stiles, W. H. and Ulaby, F. T.: The active and passive microwave response to snow parameters: 1 . Wetness, J. Geophys. Res., 85, 1037-1044, doi:10.1029/JC085iC02p01037, 1980.

Swan, A. M. and Long, D. G.: Multiyear Arctic sea ice classification using QuikSCAT, IEEE T. Geosci. Remote, 50, 3317-3326, doi:10.1109/TGRS.2012.2184123, 2012.

Tschudi, M., Fowler, C., Maslanik, J., and Stroeve, J.: Tracking the movement and changing surface characteristics of Arctic sea ice, IEEE J. Sel. Top. Appl., 3, 536-540, 2010.

Tschudi, M., Fowler, C., Maslanik, J., Stewart, J. S., and Meier, W.: EASE Grid sea ice age, [June to August 2009], NASA National Snow and Ice Data Center Distributed Active Archive Center, Boulder, Colorado USA, doi:10.5067/PFSVFZA9Y85G, 2016. 
Tschudi, M. A., Curry, J. A., and Maslanik, J. A.: Airborne observations of summertime surface features and their effect on surface albedo during FIRE/SHEBA, J. Geophys. Res., 106, 1533515344, 2001.

Tschudi, M. A., Maslanik, J. A., and Perovich, D. K.: Derivation of melt pond coverage on Arctic sea ice using MODIS observations, Remote Sens. Environ., 112, 2605-2614, 2008.

Ulaby, F. T., Moore, R. K., and Fung, A. K.: Microwave remote sensing, active and passive, Volume III: From theory to applications, Addison Wesley Pub., London, UK, 1986.

Warren, S. G., Rigor, I. G., Untersteiner, N., Radionov, V. F., Bryazgin, N. N., Aleksandrov, Y. I., and Colony, R.: Snow depth on Arctic sea ice, J. Climate, 12, 1814-1829, 1999.

Webster, M. A., Rigor, I. G., Perovich, D. K., Richter-Menge, J. A., Polashenski, C. M., and Light, B.: Seasonal evolution of melt ponds on Arctic sea ice, J. Geophys. Res.-Oceans, 120, 59685980, doi:10.1002/2015JC011030, 2015.
Willmes, S., Nicolaus, M., and Haas, C.: The microwave emissivity variability of snow covered first-year sea ice from late winter to early summer: a model study, The Cryosphere, 8, 891-904, doi:10.5194/tc-8-891-2014, 2014.

Yackel, J. J. and Barber, D. G.: Melt ponds on sea ice in the Canadian Archipelago: 2. On the use of RADARSAT-1 synthetic aperture radar for geophysical inversion, J. Geophys. Res., 105, 22061-22070, 2000.

Zege, E., Malinka, A., Katsev, I., Prikhach, A., Heygster G., Istomina, L., Birnbaum, G., and Schwarz, P.: Algorithm to retrieve the melt pond fraction and the spectral albedo of Arctic summer ice from the satellite optical data, Remote Sens. Environ., 163, 153 164, doi:10.1016/j.rse.2015.03.012, 2015. 